\title{
Representaciones visuales de la «Crisis de Refugiados»: Análisis sociohermenéutico de los textos visuales en tres diarios españoles
}

\section{Visual representations of the "Refugee Crisis»:} a socio-hermeneutic analysis of visual texts in three Spanish newspapers

\author{
Jessica Nohemí Muñoz Reyes \\ Universidad Complutense de Madrid \\ jessimun@ucm.es
}

\begin{abstract}
Resumen: En esta investigación se analizan las diversas representaciones visuales difundidas por los diarios $A B C$, El Mundo y El País a través de las fotografías publicadas de mayo de 2015 a mayo de 2016. Comenzando por un universo de 228 textos visuales, codificados en función de su descripción iconológica-iconográfica, se obtuvo un corpus de treinta imágenes, tras un proceso de selecciones sucesivas. Posteriormente, mediante un análisis sociohermenéutico, se identificó un sistema compuesto por cinco discursos: el discurso alarmista de la invasión a través de la masificación; el de la pena o compasión a través de la personificación, protección y el rescate; el incriminatorio a través de la criminalización; el de la inocencia a través de la niñez; y el de la espectacularización y exclusión a través de la difusión de la miseria. Además, analizando las interacciones y relaciones entre ellos, se constató que fueron principalmente dos discursos los predominantes durante el periodo analizado, ofreciendo una trasformación en la manera como fueron representados los refugiados. Favoreciendo la estigmatización de la otredad, bien legitimando el mensaje de «crisis incontrolable», bien señalándolos como sujetos indefensos y victimizados.
\end{abstract}

Palabras clave: Refugiados, crisis migratoria, representaciones visuales, análisis sociohermenéutico, fotoperiodismo, metodología audiovisual.

Abstract: This study analyses the diversity of visual representations generated through photographs published by the newspapers $A B C$, El Mundo and El País, from May 2015 to May 2016. Starting from a universe of 228 visual texts, codified 
according to their iconological-iconographic description, I obtained a sample of 30 images after a successive selection process. Afterwards, using a socio-hermeneutic analysis was possible to identify a system composed of five discourses, receiving the following names: the alarmist discourse of the invasion through massification; the discourse of pity or compassion through personification, protection and rescue; the incriminatory discourse through criminalization; the discourse of innocence through childhood; and the spectacularization and exclusion through the dissemination of misery. In addition, analysing the interactions between them, it became evident that mainly two discourses were predominant during the period analysed, offering a transformation in the way refugees were represented. Favouring the stigmatization of otherness, either legitimizing the message of «uncontrollable crisis», or pointing them out as defenceless and victimized subjects.

Keywords: Refugees, migrant crisis, visual representations, socio-hermeneutic analysis, photojournalism, audio-visual methodology. 


\section{INTRODUCCIÓN}

En la última década, los crecientes problemas políticos y conflictos armados en países como Siria, Afganistán, Nigeria (por mencionar algunos) han forzado a un cierto número de personas a dejar sus hogares, debido a la permanente amenaza que sufren sus derechos humanos. Reavivando antiguos debates sobre flujos migratorios, que no son más que «nuevos contenidos de una pasión antigua: la discriminación [...] del foráneo y su estigmatización en tanto que 'otro'» (Sassen, 2013a: 16). Esta problemática de la creciente llegada de refugiados ha tenido especial cobertura en los medios por lo menos durante los últimos ocho años, generando, en su mayoría, imágenes descontextualizadas que a primera vista evocan una «invasión masiva».

Por su parte, la literatura sociológica encontrada sobre el tema se focaliza en alguna región específica o un medio y análisis concreto (como el análisis de contenidos). Y, aunque se han encontrado algunos trabajos que exploran el tratamiento de materiales visuales, se echa en falta un análisis que aborde el uso de imágenes como sistema de discursos insertos en un contexto social, económico y político concreto. Es así que la presente investigación plantea identificar las representaciones visuales de los refugiados, construidas a través del fotoperiodismo en algunos diarios españoles durante el periodo de inicio de la «crisis». Para ello, se plantearon preguntas como: ¿qué imagen se construyó en España sobre los refugiados a través de las fotografías periodísticas durante 2015 y $2016^{1}$ ?; ¿ ¿hubo diversidad de discursos comunicados o se centró todo en uno solo?; ¿hubo alguna transformación en la forma de representarlos o se mantuvo un discurso constante durante ese periodo?

Cobra relevancia por su aportación desde el punto de vista social, al abordar la difusión de «una crisis» con gran impacto en la imagen de los refugiados y las sociedades receptoras; sociológico, al cuestionar los discursos de los medios y su interacción desde una perspectiva hermenéutica; y metodológico, al hacerlo bajo una propuesta innovadora como lo es el análisis periodístico a través de los «textos visuales» (Abril, 2012a: 16).

\section{CONTEXTUALIZACIÓN: LA «CRISIS DE REFUGIADOS» EN CIFRAS}

Con el objetivo de dimensionar esta situación denominada «crisis» (útil también para deshacernos de la idea de «invasión», y cuestionarnos sobre las imágenes mentales

${ }^{1}$ Periodo en el cual se concentró la atención de los medios. En un próximo epígrafe se expondrá la justificación a esta selección de fechas concretas. 
de masividad), es interesante partir de los reportes anuales sobre las Migraciones Forzadas. Tan solo en el informe de 2017 se menciona que en ese año se registraron 68,5 millones de desplazamientos forzados ${ }^{2}$ en total (UNHCR, 2017: 2). Es decir, que, contrastando con la población mundial, alrededor del $1 \%$ se ha visto forzado a dejar su hogar debido a la amenaza por persecución, conflictos armados o violencia en general. Entre ellos, poco más de un tercio (25,4 millones) son exclusivamente personas en situación de refugio a nivel mundial ${ }^{3}$.

Además, esta situación se ha desenvuelto en un contexto político, social y económico complejo, ante una comunidad expuesta a choques de posturas entre dirigentes y ciudadanos, provenientes desde 2008 tras los planes de austeridad de cara a la recesión económica (Onghena, 2015a: 8). Mientras tanto, el «estado de alerta» contra las personas musulmanas se mantiene y refuerza a través de asociaciones directas de ellos con terroristas, presentándolos como potencial amenaza. Tal fue el caso del político neerlandés Geert Wilders ${ }^{4}$, quien, buscando infundir miedo, mantuvo un discurso xenófobo hablando de las migraciones como un «tsunami islamista», peligroso para la preservación de la cultura y la seguridad de la población (Onghena, 2015b: 9). Este ejemplo, como muchos otros ${ }^{5}$, alimenta un discurso de odio, miedo y desconocimiento que genera en su conjunto un ambiente de menor tolerancia y complica el escenario para quien viene «de fuera», un outsider.

Como reflejo de estas actitudes proteccionistas, hemos presenciado cierres de fronteras $^{6} \mathrm{y}$ otras trabas a quienes buscan ayudar a los solicitantes de refugio ${ }^{7}$, ocasionando grandes concentraciones en un número contado de países. Tal es el caso de Turquía ${ }^{8}$, que ha recibido «a más personas refugiadas que el conjunto de los 28 estados miembros de

2 Tanto de refugiados como de personas en búsqueda de asilo y personas desplazadas internamente.

${ }^{3}$ Y que, según el mismo informe (UNHCR, 2017), son personas provenientes principalmente de Siria (6,3 millones), seguidos de Afganistán (2,6 millones), Sudán del Sur (2,4 millones) y Myanmar (1,2 millones).

${ }^{4}$ Líder del Partido por la Libertad, de orientación ultraderechista en Países Bajos,

${ }^{5}$ Ver el caso "fake news», donde fuerzas políticas extremistas buscan dispersar miedo para conseguir más seguidores: The Observers(2018), disponible en https://observers.france24.com/en/20180105-fake-images-racist-stereotypes-migrants

${ }^{6}$ Como el implementado por Hungría en 2015 en los límites con Serbia y un mes después en la frontera con Croacia. EFE (16 octubre de 2015), disponible en https://www.efe.com/efe/america/sociedad/hungria-cierra-una-segunda-frontera-la-croata-para-detener-inmigracion/20000013-2739480

7 Ver, por ejemplo, el Acuerdo UE-Turquía de marzo 2016. CEAR (2018), disponible en https://www. cear.es/dos-anos-del-acuerdo-la-ue-turquia/

${ }^{8}$ Que lidera el puesto como principal receptor con 3,5 millones de refugiados, casi el 14\%. 
la Unión Europea» (CEAR, 2018a: 9). Y es que, según datos del Banco Mundial (2018), en 2017 había dos millones (un 9\%) de refugiados en toda la UE, lo cual representaría apenas el 0,4\% de la población total de la misma. Así que, sin intención de restar importancia al tema, no parece que haya habido un «tsunami de refugiados» como algunos medios comunicaron.

Aun cuando la proporción de refugiados en la Unión Europea es relativamente baja, la difusión de las llegadas por el Mediterráneo despertó la necesidad de establecer acuerdos, para «repartirlos» a través de programas de reasentamiento y reubicación. Sin embargo, a inicios de 2017, la Comisión Europea comunicaba ya que solo recibiría un $25 \%$ de las 160.000 personas que se habían comprometido a ayudar, como parte de esos acuerdos de reubicación (CEAR, 2016: 9). España, por ejemplo, hablaba del compromiso de recibir 17.387 personas y, aunque sí aumentó la acogida en los últimos tres años, a 1 de junio de 2017 apenas había recibido al 7,5\% y había concedido el estatuto de refugiado ${ }^{9}$ a 595 personas (CEAR, 2018b: 10).

Dicho contexto político y social, aunado a los debates entre países e instituciones sobre el tema, nos hace reflexionar sobre el papel que han mantenido los medios de comunicación en la construcción de una crisis, por su forma de dimensionar la problemática. Igualmente, nos hace cuestionarnos la manera de representar al refugiado como actor social en un escenario sociopolítico concreto. Después de todo, «es imposible ignorar el rol de los medios masivos en la influencia que ejercen sobre las actitudes del público y la élite política en relación al tema de asilo y refugiados» (Berry, García-Blanco y Moore, 2015a: 5).

\section{MARCO TEÓRICO Y ANTECEDENTES}

El tema de los movimientos mixtos (migrantes y refugiados) no es nuevo ni desconocido en Europa. Lo cierto es que, como mencionara Sassen (2013b), pareciera que recientemente se ha ido construyendo y decodificando el tema del refugio como un suceso «tercermundista». De hecho, las múltiples causas del flujo de personas (globalización, dinámicas económicas, persecuciones, entre otras) se han visto simplificadas y englobadas en un solo motivo: «la desesperación» como catalizador o movilizador. Pro-

9 Si bien la concesión se basa en lo establecido por la Convención de Ginebra (1951), cada Estado miembro establece sus propios criterios para conceder o no dicho estatuto. Para consultar los criterios para la valoración de cada caso de solicitud de refugio, ver el Boletín Oficial del Estado con referencia BOE-A-2009-17242. 
vocando que la fina línea entre migrantes y refugiados se vaya desdibujando aún más, y así, «la pregunta 'quién es un refugiado' se complica por la creencia cada vez más difundida de que se trata de migrantes económicos disfrazados de víctimas políticas» (Sassen, 2013c: 34). Llevando no solo a la confusión o mal uso de términos (a veces de forma intencional), sino también a que el colectivo de refugiados sufra los mismos estigmas, generalizaciones y estereotipos, restando importancia a la necesidad de asilo y poniendo en riesgo la vida de quienes necesitan este reconocimiento internacional.

\section{Migrantes y refugiados: una breve referencia a la evolución de su imagen y conceptualización}

Esta imaginería negativa antes mencionada no fue siempre así. De hecho, según la misma autora, la imagen del migrante y refugiado ha pasado por varias etapas de reconfiguración. Sin embargo, antes de entrar en los debates sociológicos sobre ambos términos, resulta pertinente comenzar estableciendo la diferencia «objetiva» entre ellos, según las definiciones oficiales propuestas por organismos como la ONU o la OIM. Mientras el migrante económico es alguien que decide voluntariamente dejar su lugar de residencia e instalarse en otro país buscando una mejor calidad de vida (OIM, 2006: 42), la Convención sobre el Estatuto de los Refugiados de 1951 establece que deberá ser reconocida como refugiada toda persona con temor de ser perseguida debido a su raza, religión, nacionalidad u opiniones políticas, y que no quiera o no pueda acogerse a la protección de su país (ONU, 1951: 137). Por lo tanto, este resulta un término con carga jurídica que, por ende, conlleva obligaciones legales para la comunidad internacional que lo ha convenido. De ahí la importancia de ser reconocidos y denominados bajo el concepto adecuado.

Ahora bien, volviendo a la evolución conceptual mencionada por Sassen (2013d), los migrantes económicos comenzaron siendo acogidos y bien percibidos alrededor de los siglos xvi y xvii, cuando las comunidades receptoras los veían como personas cualificadas que llevaban trabajo de calidad a lugares donde hacía falta. Esta situación, según la misma fuente, sufrió un cambio a partir de 1750, cuando las dinámicas demográficas, crecimiento descontrolado de la industria rural y recursos insuficientes generaron una nueva necesidad de movilización: la búsqueda de mejores condiciones de vida. Es a partir de este momento cuando son vistos como «vagabundos» (Sassen, 2013e: 45) y crece la noción de que quien deja su lugar de origen lo hace movido por la pobreza o la falta de oportunidades laborales.

De igual manera, la figura del refugiado sufrió un cambio en su percepción, ya que «durante el siglo xix el refugiado típico era una persona educada y culta que tenía que 
abandonar su país por motivos políticos» (Sassen, 2013f: 68). Sin embargo, hacia 1860 esta situación cambia a raíz de un nuevo motivo de movilización: las guerras y destrucciones. Provocando no solo un mayor número de refugiados, sino grupos de personas con características diferentes en comparación con los movimientos previos, ya que «los refugiados que produjeron estos acontecimientos eran pobres, y solían mezclarse con la clase trabajadora nativa» (Sassen, 2013g: 70). Es en este momento cuando, en palabras de la misma autora, convergen tanto migrantes laborales como refugiados en sociedades receptoras ya afectadas por una escasez de trabajo. Lo cual lleva a la aparición de cierto rechazo y búsqueda de control, ocasionando una sola reacción: la necesidad de protección ante una amenaza externa inminente..., la de «los otros».

\section{Movimientos mixtos: la estigmatización de la otredad}

Como ya se ha mencionado, sea por desconocimiento, confusión o mal uso de términos, el colectivo de refugiados ha llegado a sufrir acusaciones similares a las que enfrentan los migrantes económicos, y a través de la imprecisión o difusión de ciertas imágenes en los medios van reforzándose dichos imaginarios negativos para ambos. De ahí que hoy seamos testigos del fortalecimiento de discursos extremistas y la aceptación (en determinados sectores/medios) de ideologías de ultraderecha, complicando la situación para quienes buscan oportunidades económicas, pero también poniendo en riesgo la vida de quienes huyen de la persecución y la guerra. Por ello, para la mejor comprensión del imaginario que puede llegar a evocar el término refugiado, parece necesario detenerse a entender la estigmatización del término migrante en tanto que «extranjero», producido en las sociedades contemporáneas.

En el caso de Europa, se vivía ya desde 2011 (incluso desde antes) cierto recelo hacia los migrantes ${ }^{10}$, ya sea por «la amenaza» que representan a las oportunidades laborales o por la mala imagen construida tras mucho tiempo de asociaciones con comportamientos desviados ${ }^{11}$. «Etiquetas» que van permeando en la sociedad y que, junto con su «estatus del forastero [outsider], el que no pertenece a la comunidad establecida» (Sassen, 2013h: 22), estigmatizan a dicho colectivo ${ }^{12}$. Este tipo de estigma, que Goff-

${ }^{10}$ Comisión Europea (2011). Qualitative Eurobarometer: Migrant Integration. Aggregate Report May 2011. Disponible en https://ec.europa.eu/commfrontoffice/publicopinion/archives/quali/q1_5969_migrant_ en.pdf

${ }^{11}$ Criminales o infractores de la ley (evasión de impuestos, corrupción, entre otros).

${ }_{12}$ Ver, por ejemplo, el Eurobarómetro Standard 90 (Comisión Europea, 2018), donde a más de la mitad de los europeos les evoca un sentimiento negativo la inmigración de personas de fuera (de la Unión Euro- 
man (2006a) llama «tribal», hace referencia a la raza o nación a la que pertenece un individuo; elementos transmitidos entre generaciones que «afectan» a todo el conjunto por el simple hecho de compartir un rasgo de pertenencia, señalándolos como indeseables. De manera que se va construyendo ante esta situación «una ideología para explicar su inferioridad y dar cuenta del peligro que representa esa persona, racionalizando a veces una animosidad que se basa en otras diferencias $[\ldots y$ y tendemos a atribuirle un elevado número de imperfecciones» (Goffman, 2006b: 15). Cobrando relevancia el estigma de ser considerado «forastero» u outsider.

En este sentido, la definición que plantea Becker (2009a) sobre el outsider (un marginal) se fundamenta en las reglas sociales y la forma en cómo se ejercen sobre un individuo. Menciona que «la visión sociológica define la desviación como la infracción a algún tipo de norma acordada [... e] ignora el hecho central: la desviación es creada por la sociedad» (Becker, 2009b: 28). Es decir, es la reacción de la sociedad ante una actitud establecida como incorrecta la que marca a alguien como desviado. Por lo tanto, se entiende que cuanto mayor gravedad percibida del acto y menor probabilidad de ser algo que «yo haría», mayor será el grado en el cual una persona será considerada marginal.

De esta forma, los migrantes no solo cargan consigo el estigma «tribal» de ser considerados los «otros» (quienes no pertenecen), sino que, como se establece en el trabajo de Becker, se ven marginados al relacionarse con actitudes o comportamientos inaceptables para las normas de la sociedad receptora. Por esta razón, y debido al paralelismo entre ambos términos (migrantes y refugiados), de alguna forma se espera que cumplan con los estereotipos ya establecidos, generalizando el comportamiento a todo el colectivo. Limitando y complicando las interacciones no solo por la presencia de diferencias culturales, sino por esta presencia de estigmas y estereotipos masificados, que fomentan la protección de «lo nuestro» y reducen la empatía con «el otro».

\section{Procesos de representación: los estereotipos y la mediatización}

Es así que, al estudiar el tema de las representaciones sociales, parece relevante detenerse a hablar sobre los estereotipos. Después de todo, son los que «nos hablan del

\footnotetext{
pea), mientras que apenas el $30 \%$ siente lo mismo respecto de la inmigración de integrantes de la Unión. A su vez, resulta ser una de las dos preocupaciones más grandes a nivel Europa, mencionado por el $21 \%$ como uno de los principales problemas que afronta su país. Sin embargo, en España el 37\% tiene una percepción negativa hacia la inmigración de personas externas a la UE, mientras que la inmigración preocupa a 2 de cada 10 (detrás del desempleo, la situación económica y las pensiones).
} 
mundo antes de verlo. Imaginamos la mayoría de las cosas antes de experimentarlas. Y esas ideas preconcebidas, a menos que la educación nos haya hecho muy conscientes, gobiernan profundamente todo el proceso de percepción» (Lippmann, 1921: 60).

Según Hall (1997a), estereotipar es una forma de identificar características memorables y fácilmente reconocidas de una persona, reduciéndolo a un conjunto de elementos que lo despojan de cualquier otra cualidad, y lo simplifican en una categoría fija a lo largo del tiempo. Esto responde a la necesidad de identificar a las personas en función de sus diferencias, estableciendo lo que es aceptable e inaceptable. Por lo tanto, para él, utilizar estereotipos «es parte del mantenimiento del orden social y simbólico. Marca la frontera simbólica entre lo normal y lo desviado [...] entre los de 'adentro' y los de 'afuera', Nosotros y Ellos» (Hall, 1997b: 258).

Como se mencionaba ya al inicio de este epígrafe, estos estereotipos están estrechamente ligados a los procesos de representación, al ser un vehículo a través del cual se percibe al individuo, se interioriza, se le reconstruye y clasifica, buscando comprenderlo dentro de nuestro contexto social, cultural, etc. Sin embargo, aunque este sea el motivo esencial, Hall (1997c) menciona que los estereotipos se convierten en un ejercicio de violencia simbólica, cuando dicha representación social se realiza como forma de ejercer el poder. Y es que «no son los estereotipos, como un aspecto de pensamiento y representación humana, lo que está mal, sino quien los controla y define, y los intereses a los que sirven» (Dyer, 1999: 1). En esta misma línea, sobre los procesos de reproducción de la realidad, es importante considerar que «la representación de un objeto no es idéntica al objeto real. Es reproducción de ese objeto en el sentido de reinterpretación [y] reformulación [...] a través de su concepción del mundo, sus marcos de referencia, su posición social» (Belarbi, 2004a: 88). Por lo tanto, toda representación se verá influenciada por el contexto de reproducción y de recepción, por la intención del autor y de quien la difunde, los intereses de terceros actores, los conocimientos e ideas previas de quien lo recibe, entre otros tantos elementos. Y es en este proceso de deconstrucción $\mathrm{y}$ reconstrucción donde, además del lenguaje, los textos visuales ${ }^{13}$ juegan un papel fundamental. Ya que las imágenes son «la descripción de un objeto categorizado en una cultura, y también de un conjunto de atributos simbólicos más o menos abstractos que se han adherido a ese objeto» (Abril, 2012b: 21).

${ }^{13} \mathrm{Al}$ hablar de «textos» se hace referencia a cualquier método de comunicación «multimodal» fundamentado en un sistema discursivo, que puede estar integrado por elementos verbales, pero no se limita exclusivamente a ellos. Para mayor detalle, consultar Abril (2012), «Tres dimensiones del texto y de la cultura visual». 
En este sentido, sobre las representaciones sociales de los movimientos mixtos, se ha apuntado que «en la designación de estos recién llegados [...] reina la imprecisión terminológica. La figura del extranjero se ha construido y se ha fijado jurídicamente con la afirmación del Estado-nación» (Belarbi, 2004b: 89). Y así, en conjunto con los elementos lingüísticos, los textos visuales van reforzando los estereotipos existentes o legitimando esa confusión terminológica, ofreciendo una vía de simplificación de la problemática y tratándola como una herramienta política/ideológica más. Es allí donde cobran relevancia los medios de comunicación, como vehículo a través del cual la sociedad va construyéndose una idea sobre una situación y como herramientas de la agenda setting ${ }^{14}$. Después de todo «los medios de difusión pueden influir en qué temas se incluyen en la agenda pública. Pero quizás es más importante que los medios de difusión puedan influir en el modo en que la gente piensa sobre los temas de la agenda pública» (McCombs y Evatt, 1995: 2).

\section{Estudios previos sobre la mediatización de la «crisis de refugiados»}

Tal como plantean Georgiou y Zaborowski (2017a: 3), «la prensa europea tuvo un papel central en la representación de las llegadas de refugiados y migrantes [...] como una crisis para Europa». Según este estudio longitudinal en ocho países europeos ${ }^{15}$, se observó una evolución general en la manera de representar y hablar de esta situación, pasando de una tendencia a la simpatía/empatía hasta la sospecha y hostilidad ${ }^{16}$. Así

${ }^{14}$ Término que se refiere al papel de los medios para señalar ciertos acontecimientos en el entorno y «traducir» los hechos desde el ámbito público al entendimiento privado (de cada persona en su contexto), convirtiéndolo en un tema relevante para el público/la sociedad. Para más detalle, consultar McCombs y Evatt (1995), «Los temas y los aspectos: explorando una nueva dimensión de la agenda setting».

${ }^{15}$ En el cual se analizan y comparan 1.200 artículos de prensa (en República Checa, Francia, Alemania, Grecia, Hungría, Irlanda, Serbia y Reino Unido) publicados inmediatamente después de tres momentos específicos durante 2015: Hungría construyendo una barrera en la frontera con Serbia (julio), la publicación de la imagen del pequeño sirio de tres años Aylan Kurdi (septiembre) y los atentados terroristas en París (noviembre).

${ }^{16}$ El primer periodo es llamado «tolerancia cuidadosa», tras el incremento de imágenes y reportajes sobre las llegadas de refugiados a las costas europeas, llevando a la decisión de Hungría de cerrar fronteras para detener el «flujo migratorio». El segundo periodo lo llaman «euforia humanitaria» (ecstatic humanitarianism), debido al interés frenético por el lado humanitario de la «crisis» tras la fotografía de Aylan Kurdi. Y al tercer periodo lo han llamado «miedo y securitización», por el cambio radical en la forma de representación realizada por los medios y la reacción de la sociedad ante los atentados en París. 
mismo, destacan el poco o nulo derecho otorgado a los refugiados para hablar y representarse a sí mismos, apareciendo como personajes sin voz, descontextualizados y referenciados como una masa sin diferencia de nacionalidad o profesión. Manteniéndose en una constante dualidad a través de «la masificación, que los describe simplemente como un número, una referencia estadística o una masa indiscriminada de desafortunados; y la pasividad, que los describe principalmente como cuerpos pasivos necesitados que no pueden actuar en sus circunstancias» (Georgiou y Zaborowski, 2017b: 9).

Así mismo, como parte de esta masificación y como ejemplo de la imprecisión terminológica, Berry et al. (2015b), en su estudio comparativo realizado para la ACNUR ${ }^{17}$, encuentran que en España, por ejemplo, predominó el término inmigrante (70\%) como descriptor, mientras que el de refugiado apenas aparece (10\%), «revelando la renuencia a reconocer los difíciles contextos políticos de los que los individuos pueden estar huyendo» (Berry et al., 2015c: 71). Por último, concluyen que la cobertura de los medios estuvo centrada en el Estado-nación, politizando la situación al enfocarse en términos numéricos (cumplimiento de cuotas, costos de la migración, etc.), demostrando, así, cómo «[...] los flujos migratorios en el Mediterráneo son construidos principalmente como un problema» (Berry et al., 2015d: 74).

Ahora bien, los estudios antes referenciados demuestran el papel que jugaron los medios en la construcción y difusión de una «crisis» en el plano de lo verbal. Sin embargo, no hay que olvidar que las imágenes ofrecen narrativas y discursos igualmente potentes y, aun así, «las metodologías visuales están relativamente infrautilizadas para explorar cómo las nociones del refugio (refugee-ness) están construidas y perpetuadas para formar la opinión pública sobre las personas en búsqueda de asilo y los refugiados» (Lenette, 2017a: 1). Y es que, cuando comenzaron a saberse los hechos fatídicos del Mediterráneo, no tardaron en difundirse materiales audiovisuales sobre el suceso, sin que se tuviera el contexto ni el entendimiento necesario sobre la situación ${ }^{18}$; simplificándose a través de elementos que generaran familiaridad ${ }^{19} \mathrm{y}$ conectaran con ideas ya interiorizadas.

${ }^{17}$ Donde se aborda la temática igualmente a través de un análisis de contenido comparativo entre cinco países de la Unión Europea (España, Italia, Alemania, Reino Unido, Suecia), con una muestra de 1.500 artículos de prensa escrita durante todo un año (2014 y principios de 2015).

${ }_{18}$ Por ejemplo, Ruiz-Aranguren y Cantalapiedra-González (2018) plantean la escasa presencia de integrantes con preparación o especialización en temas de inmigración, que sirvan de guía para combatir el racismo dentro de los equipos periodísticos.

19 Por ejemplo, Wright (2002) comenta que en las fotografías de refugiados se frecuentan marcos basados en iconografía cristiana (con imágenes que hacen relación al «éxodo»), o que frecuentemente se enfocan en mujeres y niños, con el objetivo de comunicar «vulnerabilidad» y buscando despertar empatía. 
Estos elementos son tratados por Lenette (2017b) en el estudio de las representaciones visuales de los campos de refugiados ${ }^{20}$, basándose en el trabajo de Kurasawa (2013) sobre el «sentimentalismo humanitario» ${ }^{21}$ y la forma de evocarlo, a través de imágenes de sufrimiento y marginalidad. La autora propone siete tópicos o encuadres ${ }^{22}$ recurrentes en la fotografía de situaciones de crisis, los cuales se presentan a continuación de manera breve:

- Personificación: representado mediante un solo individuo o grupo pequeño, en condiciones precarias, evocando pena. Generalmente utiliza la técnica del primer plano.

- Masificación: representado a través de una masa de gente, difícilmente identificable, que agrava o refuerza la situación de «crisis» y evoca repugnancia.

- Interés/cuidado: representado a través de las interacciones entre ONG con las personas necesitadas, evocando simpatía.

- Rescate: representado mediante una interacción desigual entre grupos de ayuda humanitaria y víctimas, planteándolos como actores pasivos y evocando nobleza.

- Feminización: se presenta a mujeres con niños en brazos, buscando despertar la empatía (y motivar la donación).

- Niñez: la representación de niños como símbolo de inocencia en situaciones de sufrimiento, que despiertan compasión.

- Criminalización: se presenta a un grupo, frente a elementos con una carga negativa, connotando prisiones (las rejas, por ejemplo).

En algunos de los casos, estos encuadres se ven potenciados por las ya existentes «narrativas antinmigratorias» (Fernández de Castro y González-Páramo, 2019a: 4) que han ido permeando y afianzándose en el imaginario colectivo, impactando igualmente las percepciones y creencias sobre los refugiados. Algunos de los elementos en los que se basan estas narrativas, según este estudio, son:

${ }^{20}$ Cuyo abordaje consta de un análisis de siete imágenes, utilizadas por ONG u organizaciones humanitarias, bajo el esquema del sentimentalismo humanitario.

${ }^{21}$ Ver Kurasawa (2013), «The sentimentalist paradox: on the normative and visual foundations of humanitari-Anism».

${ }^{22}$ Cuatro de los cuales son propuestos por Kurasawa y recuperados por Lenette (personificación, masificación, interés/cuidado y rescate) y el resto (feminización, niñez y criminalización), propuestas de la autora como resultado de su trabajo sobre representaciones de refugiados. 
- El económico: hablando del robo de trabajos y servicios públicos.

- El identitario: sobre la pérdida de la «esencia» nacional, por la mezcla con personas de fuera.

- El de seguridad: que refleja el temor por la llegada de «delincuentes y terroristas».

Además, «el rechazo al extranjero se magnifica en el caso de algunos inmigrantes. En concreto, la «franquicia» explota de manera recurrente tres recursos: la islamofobia, la aporofobia (odio al pobre) y la crimigración (el migrante, sobre todo irregular, como sospechoso)» (Fernández de Castro y González-Páramo, 2019b: 5). Es por causa de estos elementos que hoy presenciamos cada vez con mayor frecuencia situaciones que parecerían impensables algunos años atrás. Un ejemplo que plantea esta misma fuente es el caso de España, que por mucho tiempo fue el país excepción ante estos comportamientos nacionalistas, sin embargo, hoy ve surgir el apoyo a partidos de ultraderecha (como sucediese con VOX en estas últimas elecciones nacionales). Razón por la cual resulta aún más interesante abordar la forma en que los medios españoles han tratado esta situación de las llegadas de personas refugiadas.

\section{METODOLOGÍA}

Esta investigación, planteada bajo el paradigma interpretativo, busca identificar las representaciones visuales de la «crisis de refugiados» a través del análisis de los materiales visuales reproducidos y difundidos por la prensa española ${ }^{23}$. Se abordaron específicamente los periódicos ABC, El Mundo y El País, de mayo de 2015 a mayo de 2016, al ser tres de los diarios más importantes en España, de manera que se contara con diferentes miradas, posturas ideológicas y una mayor diversidad de discursos.

El proceso comenzó con la búsqueda de imágenes en las hemerotecas digitales utilizando los tesauros «refugiados, Europa, Mediterráneo, crisis», para seleccionar aquellas que cumplieran con ciertos criterios ya preestablecidos ${ }^{24}$. Habiendo obtenido

${ }^{23}$ Cabe destacar que, aunque se conoce la relevancia del contexto de producción en el análisis audiovisual, esta investigación se centra exclusivamente en la parte iconográfica e iconológica, quedando fuera del objetivo de la misma el análisis del texto escrito en las noticias como forma de contextualizar las imágenes seleccionadas.

${ }^{24}$ No se consideraron las páginas de los diarios donde no se observaron refugiados (o símbolos relacionados a ellos) en las imágenes. Por lo tanto, fueron excluidas imágenes de políticos, personalidades de ONG, mapas, manifestaciones a favor de la causa, infografías o gráficos, al no aportar valor al objetivo del estudio. 
un universo de 228 textos visuales (y dada la limitación de recursos debido a la naturaleza académica del proyecto), se buscó enfocar los esfuerzos en una selección estratégica. Por lo tanto, se realizó un abordaje mediante etapas de selecciones sucesivas (motivadas por criterios de pertinencia y diversificación estructural), basadas en aproximaciones exploratorias al universo de materiales y en la literatura consultada previamente.

La primera etapa consistió en un análisis de contenidos del universo, de manera que se tuvieran clasificadas las imágenes en función de su descripción. Para ello, se utilizó el primer y segundo nivel del abordaje iconológico-iconográfico de Panofsky (1970) ${ }^{25}$, registrando los elementos de los 228 textos desde un plano descriptivo (personajes, lugares, situaciones, etc.). Posteriormente, habiendo identificado características comunes mediante esta técnica, se construyó un sistema de códigos para agrupar las imágenes y formar grandes espacios semánticos ${ }^{26}$. Dentro de estas subcategorías, teniendo en mente la representatividad estructural, se realizó finalmente una selección de las imágenes más características para obtener una muestra restringida y abordable con mayor profundidad.

Una vez conformado el corpus, se abordó bajo la perspectiva del análisis sociológico del sistema de discursos de Conde (2009a). Por lo tanto, se construyó un mapa de las diferentes posiciones discursivas, donde se analizó de manera más detallada cada imagen según el conjunto de símbolos, colores destacados (y las emociones transmitidas), la técnica fotográfica (enfoque, composición, uso del espacio, etc.), sin olvidar las diferentes miradas ${ }^{27}$ a las que puede aludir la propia imagen. De esta forma, fue posible vi-

${ }^{25}$ Según este autor, el primer nivel consiste en reconocer o identificar los elementos característicos en las imagines, en su manera más pura (es decir, formas, colores, personas, actividades...). A esta enumeración de elementos él la llama «descripción pre-iconográfica» (Panofsky, 1970: 54). Posteriormente, el segundo nivel, consiste en conectar y combinar esos elementos con temáticas, traduciéndolas en conceptos o dándoles un significado, a través del reconocimiento de historias y alegorías.

${ }^{26}$ Es decir, grupos sistematizados según sus similitudes, contrastes e interacciones, que proporcionan diferentes significados y le dan sentido al conjunto de elementos. Ver Alonso en Conde (2009: 205).

Importante considerar que, para esta investigación, no se trabajó con términos lingüísticos, por lo tanto, estos espacios semánticos fueron construidos en función de los signos visuales de las imágenes analizadas.

${ }^{27}$ Berger (1972) destaca que al observar una imagen (hablemos de fotografías), se sabe ya de cierta forma que fue tomada con un propósito y una intención por parte del fotógrafo, es decir, que estamos viendo lo que él deseaba que viéramos. A su vez, la forma en que la miremos estará condicionada por nuestros propios conocimientos y creencias previas, ya que la mirada es un acto de elección. Con esta aproximación hacia las diferentes formas de mirar, este autor realiza una importante aportación para los estudios visuales. 
sualizar las posturas hegemónicas, relaciones y dinámica presentes entre los discursos insertos en el contexto político/social del momento.

\section{Justificación del periodo para la selección del corpus}

La delimitación del periodo parte de la literatura previa y la conclusión de que el discurso de la prensa, en el plano de lo verbal, mostró una evolución en los términos utilizados para hablar de refugiados e inmigrantes y en su forma de representación ${ }^{28}$. Es así que se optó por establecer un año para la selección de la muestra, buscando enriquecer los discursos al abarcar el principal hito ${ }^{29}$ que marcó la diferencia en la forma de narrar y decodificar la situación de los refugiados, la publicación de la fotografía de Aylan $\mathrm{Kurdi}^{30}$. Y es que, durante este periodo de euforia humanitaria, «las descripciones de medidas para ayudar a los refugiados dominaron significativamente sobre las medidas para proteger el país. [...] Por un momento por lo menos, Europa apareció con la narrativa de un lugar de (relativa) solidaridad ante la difícil situación de los solicitantes de asilo» (Georgiou y Zaborowski, 2017: 8). Cambiando, a partir de este hecho, la actitud de la sociedad hacia ellos, tendiendo a la ayuda comunitaria, las donaciones, etc.

Así que, bajo la premisa de que los medios tienen influencia directa en los temas de interés social y político (agenda setting), se utilizó la herramienta Google Trends ${ }^{31}$ para realizar pruebas de periodo y términos, así como comprobar su relevancia partiendo de la hipótesis de que el interés despertado por la producción y difusión de textos visuales se vería reflejado en las búsquedas en internet. Fijando así la pertinencia del periodo para la selección del corpus, tras explorar el comportamiento filtrado por país (España) y por búsqueda de imágenes, donde se observa cierta intermitencia en las búsquedas, y un comportamiento similar entre el término «refugiado» y «migrante» en algunos periodos (ver ilustración 1).

${ }^{28}$ Hallazgos que fueran propuestos por Georgiou y Zaborowski (2017), así como Berry et al. (2015), y que han sido ya planteados en el marco teórico.

29 Según se ha señalado en la literatura revisada.

30 Publicada en los medios el 3 de septiembre de 2015.

31 Google Trends es una herramienta gratuita de Google que permite identificar tendencias de acuerdo al nivel de búsquedas que haya tenido algún término en un periodo determinado, que se mide en valores del 0 al 100, indicando la proporción de búsquedas (Escuela de Negocios, 2014). Con esta herramienta es posible comparar términos o localizar las regiones con mayor nivel de búsquedas. En esta investigación sirvió para explorar la relevancia de los términos, según su nivel de búsquedas, y así fijar el periodo de tiempo pertinente. 


\section{ILUSTRACIÓN 1}

Gráfico comparativo de búsquedas de imágenes de «Refugiado», «Inmigrante»y «Migrante» en Google (tendencia España) durante 2015 y 2016

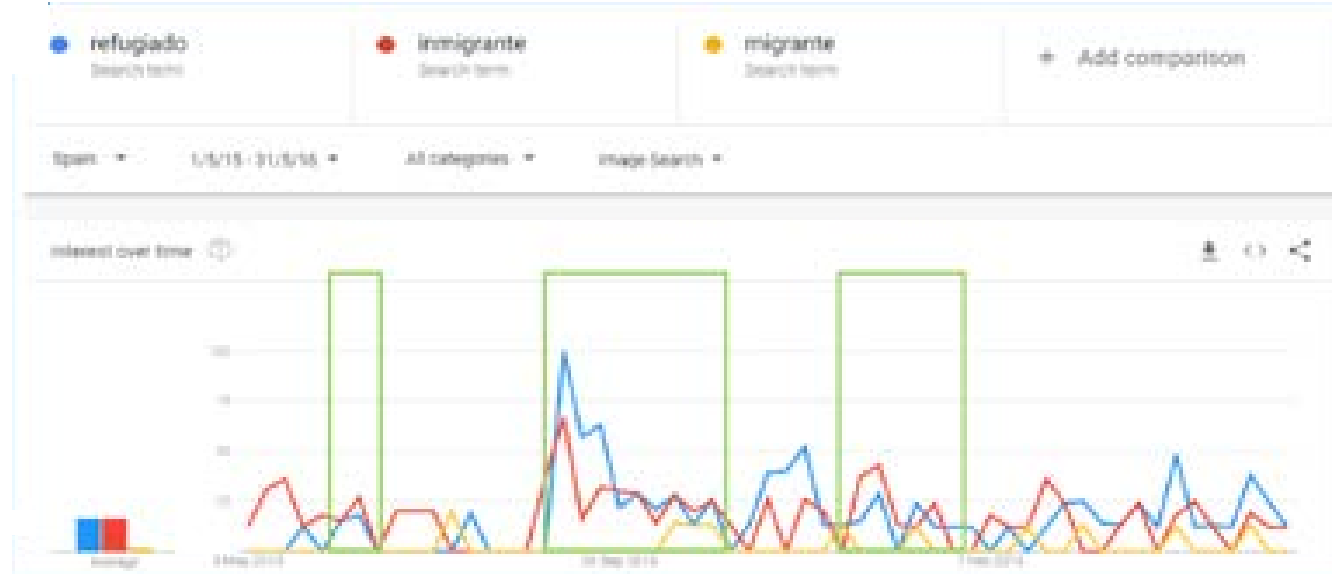

Fuente: GoogleTrends, 2018.

\section{Descripción del universo y de la muestra}

El universo, compuesto por los 228 textos visuales que cumplieron los criterios ya antes expuestos $^{32}$, cuenta con la siguiente distribución por diario y año:

TABLA 1

Distribución del universo por Diario

\begin{tabular}{|c|c|c|}
\hline Diario & Frecuencia & Porcentaje \\
\hline $\mathrm{ABC}$ & 66 & $29 \%$ \\
\hline EM & 74 & $32 \%$ \\
\hline EP & 88 & $39 \%$ \\
\hline Total & 228 & $100 \%$ \\
\hline
\end{tabular}

Fuente: Elaboración propia.

${ }^{32}$ Es importante mencionar que este estudio no pretende asegurar el uso de la totalidad de material generado por estos tres diarios durante el periodo establecido. Debido a la complejidad del manejo de las herramientas de búsqueda en las hemerotecas digitales, existe la posibilidad de haber omitido algunas imágenes que cumplían con los criterios. Sin embargo, se cuenta con una base amplia que permitió el análisis del sistema de discursos. 
TABLA 2

Distribución del universo por año

\begin{tabular}{|c|c|c|}
\hline Año & Frecuencia & Porcentaje \\
\hline 2015 & 111 & $49 \%$ \\
\hline 2016 & 117 & $51 \%$ \\
\hline Total & 228 & $100 \%$ \\
\hline
\end{tabular}

Fuente: Elaboración propia.

Como se mencionó en un epígrafe anterior, tras la primera aproximación a la composición del universo se perfilaron cinco grandes categorías o espacios semánticos. Esta estructura conformada también por su desglose de códigos representa la base para el proceso de selección de muestra del que se habló anteriormente, donde se buscó fidelidad a la diversidad de discursos del universo, respetando la representatividad estructural.

Es importante señalar que, en casos puntuales donde se quiso hacer un énfasis especial en algún discurso, se seleccionaron más imágenes de las que «correspondía» en términos de proporcionalidad. Una vez alcanzada la saturación discursiva (Ibáñez, 1986), se dejó de seleccionar material y así fue cómo se obtuvo el corpus de treinta textos visuales.

En la siguiente ilustración se presenta la estructura del universo en función de los espacios semánticos y su desglose de códigos, así como la composición final de la muestra:

\section{ILUSTRACIÓN 2}

Composición de cada espacio semántico y desglose por códigos. Estructura del universo y distribución de la muestra

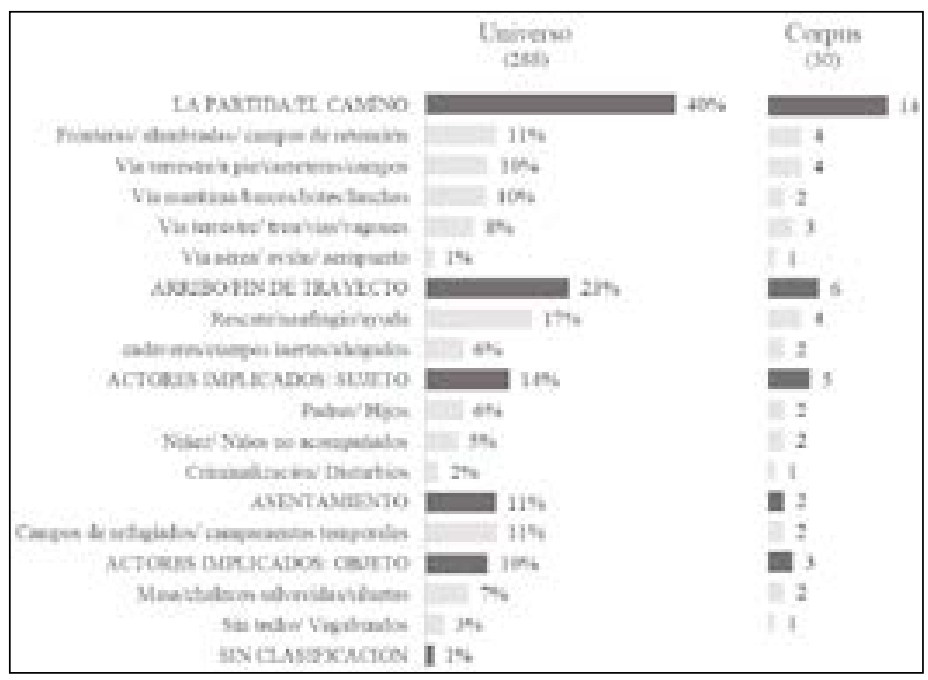

Fuente: Elaboración propia. 


\section{RESULTADOS: ANÁLISIS DE LAS REPRESENTACIONES VISUALES}

Tras haber realizado el análisis sociohermenéutico del corpus, ya vinculado con la interpretación de cada imagen en el contexto social y político, se identificaron las configuraciones narrativas que forman el hilo conductor entre los materiales analizados, viéndose cristalizadas en el mapa final de discursos como dos ejes en forma de oposición binaria.

Por una parte, se encuentra el eje de la narrativa de «El trayecto / la travesía», el cual se lee en un solo sentido (de izquierda a derecha), marcando el inicio de un camino seguido por los refugiados, hasta llegar a un final ${ }^{33}$. Dentro de este eje se localizan los tres espacios semánticos que narran estas etapas de paso:

- La partida / el camino: representa los espacios asociados a los diferentes medios de transporte utilizados para esta andanza, así como las principales barreras o adversidades que fueron encontrándose en el camino.

- El arribo / fin del trayecto: refleja los momentos críticos donde se les presenta como los necesitados, o bien como la consecuencia de no haber sido rescatados (la muerte).

- El asentamiento: representa los espacios a los que llegan estos «outsiders», ya sea como vía de descanso temporal o como el nuevo lugar donde deben intentar rehacer su vida y buscar la cotidianidad.

El otro eje se construye en relación con la narrativa «Los peregrinos / recién llegados» que refleja la mediatización del trayecto, a través del enfoque en los actores implicados en la situación. En éste, y a diferencia del anterior, los textos visuales no se centran en exponer cómo llegaron, qué obstáculos encontraron o el camino seguido, sino que enfatiza quiénes son estos «personajes» que fueron llegando, cómo son y qué es lo que traen consigo o qué van dejando a su paso (este último punto plasmado generalmente como impactos negativos de estas llegadas). Por lo tanto, el eje se divide en sentidos opuestos, extremos donde se encuentran los campos semánticos siguientes:

- Actores-objetos: se representa a estos recién llegados como objetos, a través de elementos icónicos que se convierten en un sinónimo del refugiado (por ejemplo, una pila de chalecos) y que connotan la masividad; o a través de figuras desperso-

${ }^{33}$ Este «final» no siempre es el que buscaban cuando se vieron obligados a dejar sus países. En muchas ocasiones es un asentamiento temporal o un sitio donde no se les dejó avanzar más. 
nalizadas, como entes extraños o seres marginados, estableciéndolos como actores en situaciones o comportamientos desviados.

- Actores-sujetos: se distingue como elemento principal a personajes en escenas o situaciones ya interiorizadas, que van desde la presencia del padre/madre cuidando a su hijo/a hasta escenas de disturbios. Reflejando interacciones con las que uno puede identificarse (generando empatía y cierto entendimiento) o que, en el otro extremo, refuerzan estereotipos que despiertan el rechazo y el temor. En estas escenas suele destacar la individualidad o el reconocimiento de los refugiados como personas que están siendo parte de algo (u ocasionando algo).

Debido a la interacción entre ambos ejes, en la narrativa de «El trayecto» (las etapas de «la partida, el arribo y el asentamiento»), pueden identificarse también matices que reflejan la situación a través de la mirada sujeto/objeto. Como sucede en la imagen de la derecha sobre la llegada de los refugiados, donde destacan elementos que hablan de la forma de llegada o vía de transporte (el mar y el bote), pero gracias a la toma en plano cenital se refuerza la despersonalización y el mensaje de la masividad al mostrar un conjunto de puntos dentro de un bote que «casi se desborda».

Ahora bien, una vez distribuidos los textos visuales en el mapa de discursos,

\section{ILUSTRACIÓN 3}

Fotografía de El Mundo, publicada en Noviembre de 2015, tomada por Massimo

Sestini

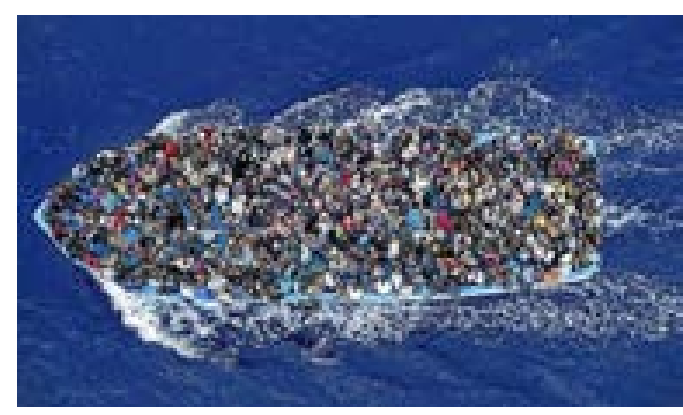
en función de ambos ejes y sus espacios semánticos, se identificaron las posiciones discursivas manifiestas, según elementos en común y las relaciones establecidas entre el conjunto de imágenes en esta muestra. Según Conde (2009b), estas posiciones discursivas establecen las perspectivas en torno a la temática a estudiar, es decir, que permiten observar la manera cómo fue abordada o comunicada la situación, así como identificar si hubo algún discurso dominante.

En esta investigación, las posiciones discursivas identificadas toman como base los siete encuadres que trabaja Lenette $(2017 \mathrm{c})^{34}$, estudio que fue utilizado como «caja de herramientas» (Foucault, 1991: 88), útil para la propia interpretación y

\footnotetext{
${ }^{34}$ Personificación, masificación, rescate, cuidado, niñez, criminalización y feminización.
} 
adaptación según la muestra analizada. Es decir, que esta investigación no pretendía poner a prueba dicha clasificación, sino más bien aprovecharla como punto de partida. De esta forma, se conservaron ciertos encuadres tal como estaban propuestos y también se realizaron ajustes o nuevas propuestas que permitieran el mejor entendimiento de los discursos generados por este corpus, resultando en el siguiente mapa de discursos:

\section{ILUSTRACIÓN 4}

Mapa de discursos: ubicación de los espacios semánticos y las diferentes posiciones discursivas identificadas

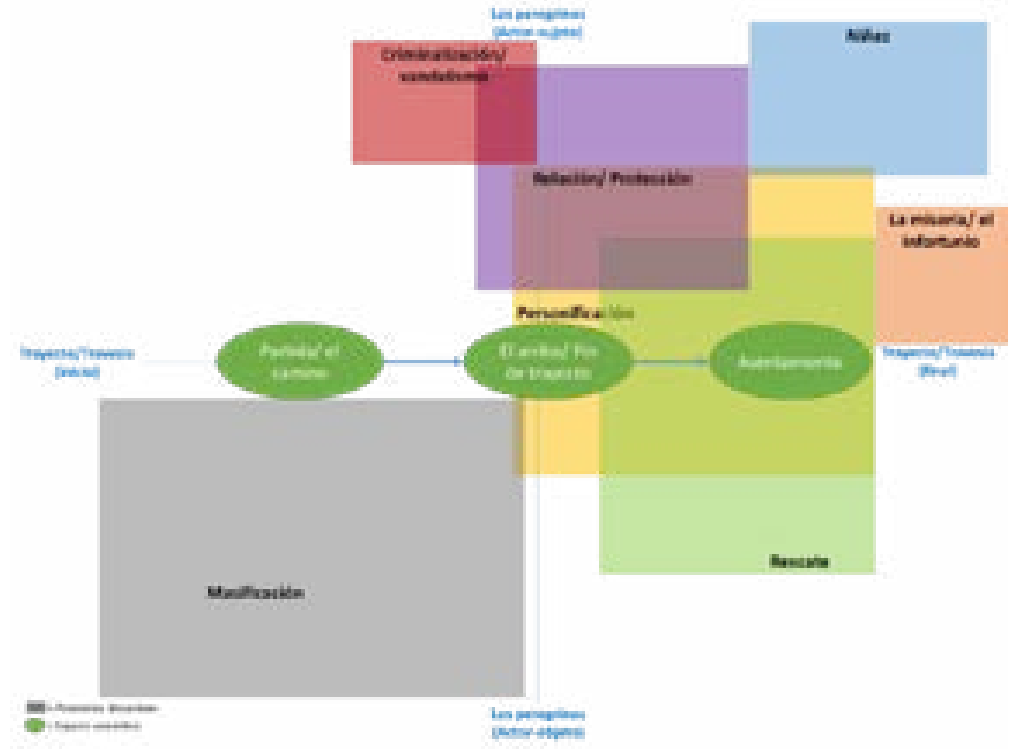

Fuente: Elaboración propia.

Es importante mencionar que, en el sistema de discursos, las posiciones discursivas no son puras ni mutuamente excluyentes. De hecho, una sola imagen puede estar conformada por diversos elementos que le permiten ser encuadrada en más de un discurso o forma de representación. Dicho esto, en el mapa antes mostrado es posible observar algunas de las interacciones entre las posiciones discursivas desde donde nos hablan las imágenes de la muestra. Por ejemplo, se observa una mayor interacción entre «la personificación», «la relación/protección»y «el rescate», casos en donde las imágenes transmiten un mensaje predominante mediante sus elementos principales, pero, a su vez, comparten otros elementos secundarios que refuerzan mensajes complementarios. 
A continuación se muestra el mapa, ahora con unas pequeñas viñetas para localizar visualmente las imágenes del corpus. Igualmente, se colocaron flechas para señalar otras interacciones menos evidentes a las que ya fueron comentadas hace un momento.

\section{ILUSTRACIÓN 5}

Mapa de discursos: ubicación de los textos visuales y sus diferentes interacciones

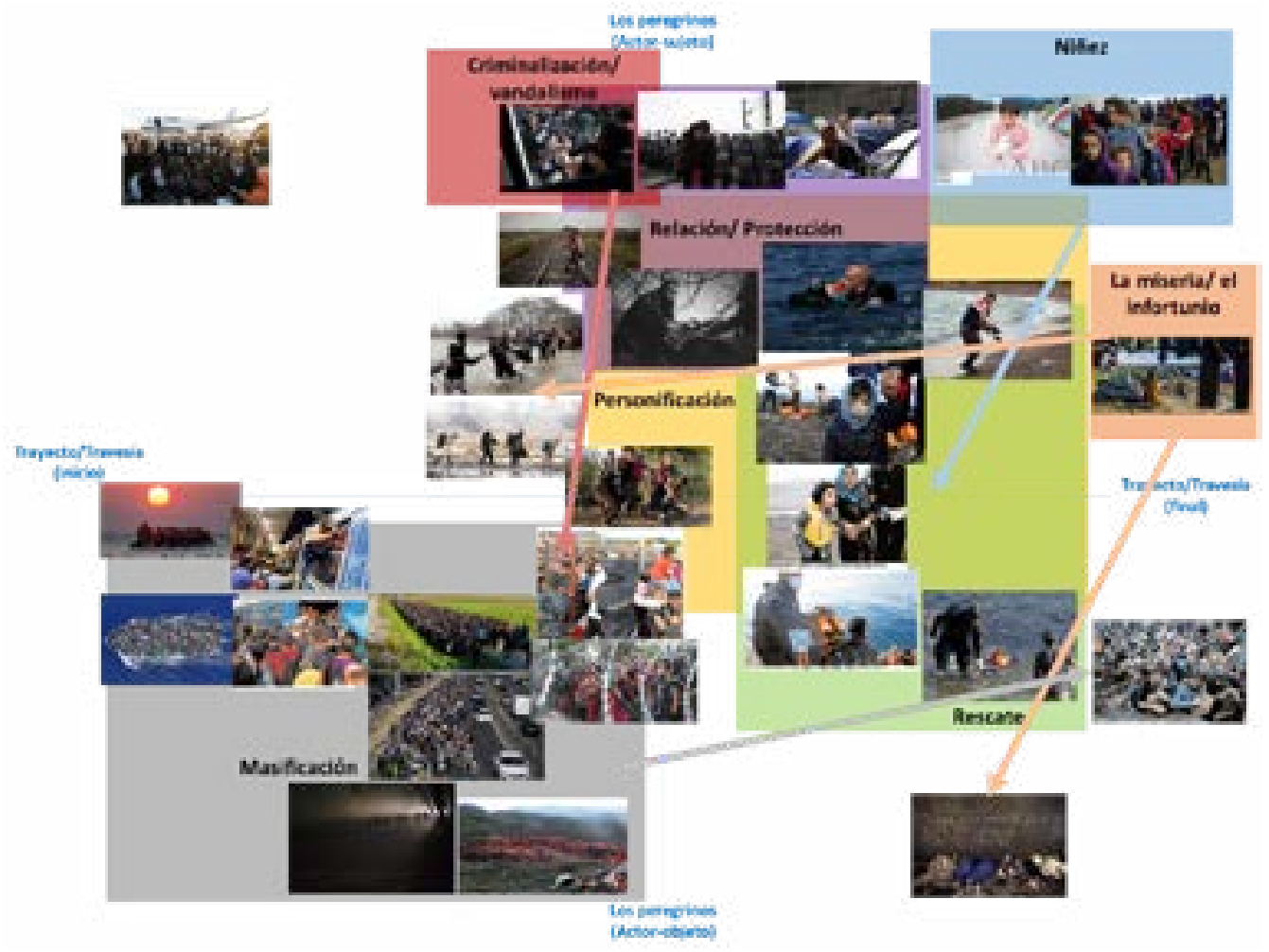

Fuente: Elaboración propia.

Por último, y antes de entrar a detalle en cada discurso, es interesante puntualizar dos cuestiones. La primera es que únicamente se localizaron dos imágenes sobre las llegadas de los refugiados por vía aérea ${ }^{35}$. Motivo por el cual, la imagen seleccionada en la muestra final no pudo ser situada en el mapa dentro de ningún discurso concreto,

35 Razón por la cual solo una imagen fue considerada dentro de la muestra, con la intención de evidenciar la aparente falta de tratamiento mediático que tuvieron estas llegadas (de las cuales, de hecho, tampoco se encontraron cifras ni información relevante). 


\section{ILUSTRACIÓN 6}

Fotografía de El Mundo, publicada en noviembre de 2015, tomada por Andrea

Bonetti, AFP.

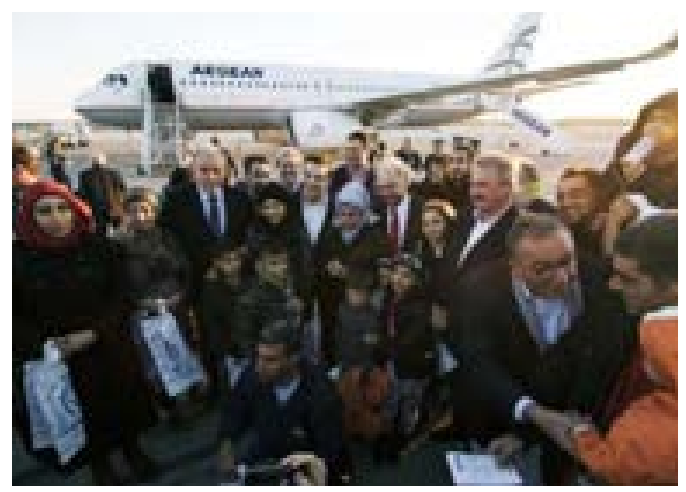

pero sí que se posicionó hacia la configuración narrativa de los actores-sujeto, al representar una escena inusualmente feliz, donde políticos dan la bienvenida de manera personalizada a un grupo «pequeño» de refugiados.

La segunda cuestión es la presencia de dos discursos dominantes en el corpus analizado: el de la «masificación» y el de la «personificación», que no parecen mantenerse constantes en relación con la «historia» contada por los medios. Es decir, si se analiza el desarrollo de la configuración narrativa relacionada con

el trayecto (inicio-fin), puede observarse que hay un predominio del discurso sobre la masificación cuando se habla del inicio del trayecto (las llegadas de los refugiados en las diferentes vías y medios de transporte, las fronteras y campos de retención). De esta manera, se legitima el mensaje de «crisis» incontrolable ante una «invasión» de grandes masas de población (los outsiders), queriendo entrar por cualquier vía posible. Sin embargo, cuando los medios se enfocan en las etapas más avanzadas durante la travesía, como lo son el arribo o el asentamiento, se observa cómo va perdiendo relevancia este mensaje (incluso va desapareciendo) y comienza a destacar el discurso de la personificación, donde se observan representaciones de interacciones entre padres e hijos (relación/protección), así como del victimismo, «los necesitados» (rescate y niñez).

Así que, habiendo visto ya cómo se configura el presente mapa de sistema de discursos, sus transformaciones e interacciones, se hablará en detalle de cada uno de los discursos generados a través de las imágenes sobre la llamada «crisis de refugiados».

\section{El discurso alarmista de la invasión a través de la masificación}

En este discurso predominan fotografías en plano completo evidenciando la magnitud de la situación, o bien en plano medio con un ángulo que da mayor profundidad a las imágenes, dejando entrever el gran grupo de personas andando o intentando pasar alguna barrera. Las imágenes tienden a estar situadas en un espacio abierto y un tanto vacío, con el cual se contrasta casi de manera automática este elemento de aglomeración, utilizado como medio para destacar el mensaje de «invasión descontrolada». 
Por ejemplo, en la imagen de la izquierda se representa la «invasión» de una autopista, donde destaca el único carril libre para los coches, ya que los otros dos han sido tomados por esa «infinita» línea de refugiados. Esta representación plantea la «masa de personas» como obstáculo o tapón al funcionamiento social, mediante el freno del flujo normal de una autopista en una ciudad que intenta seguir con su día a día. Otra metáfora sería la de la ciudad como cuerpo
ILUSTRACIÓN 7

Fotografía de El Mundo, publicada en septiembre de 2015, tomada por A. Di Lolli

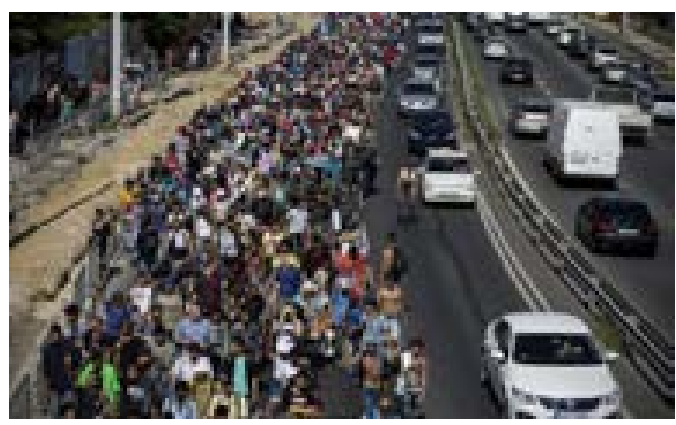
humano, que encuentra sus arterias obstruidas por un conjunto de invasores externos que no permiten el correcto funcionamiento del mismo y que terminará por enfermarlo lentamente.

Esta imagen, que además es antecedida por el titular «Cronología de la crisis de los refugiados», y descrita a pie de foto de manera imprecisa con la frase «miles de personas caminan por una carretera húngara...», sitúa la representación visual bajo el marco de una crisis (o enfermedad) que detona el alarmismo debido a una problemática grave y decisiva ocasionada por las llegadas masivas.

\section{ILUSTRACIÓN 8}

Fotografía de El Mundo, publicada en septiembre de 2015, EFE

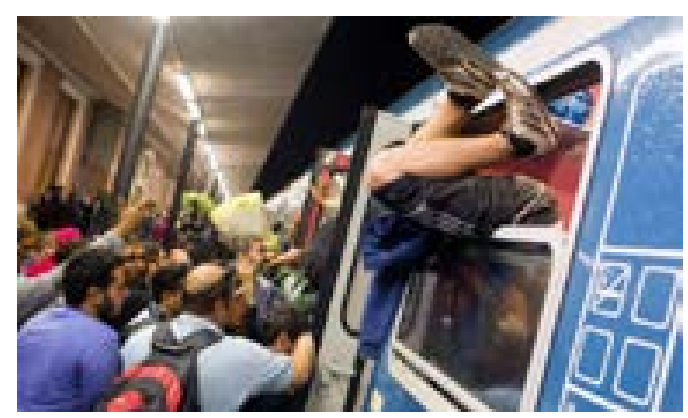

En este contraste de «lleno»y «vacío» se observan además elementos que simbolizan un contenedor de esta masa (ya sea un bote, vagón de tren o carretera), donde en algunos casos, con la técnica del primer plano que busca un mayor dramatismo, se evidencia la forma en como este contenedor se «desborda» o está a su máxima capacidad. Incluso, algunas imágenes muestran a las personas retratadas en plena acción, con posturas que transmiten un sentimiento de desesperación y desorden (gente empujándose, entrando por ventanas, etc.).

Igualmente, entre algunos de los textos visuales que pertenecerían principalmente al discurso de la criminalización/vandalismo se observa este mismo elemento de «contenedor» pero en un sentido más bien de barrera o muro de contención, simbolizando la necesidad de protección de los de adentro y plantando un límite o distancia ante esta 
amenaza exterior, marcando la diferencia entre estar dentro y fuera, entre pertenecer o ser excluido.

\section{ILUSTRACIÓN 9}

Fotografía de El Mundo, publicada en octubre de 2015, tomada por Gyorgy Varga, EFE

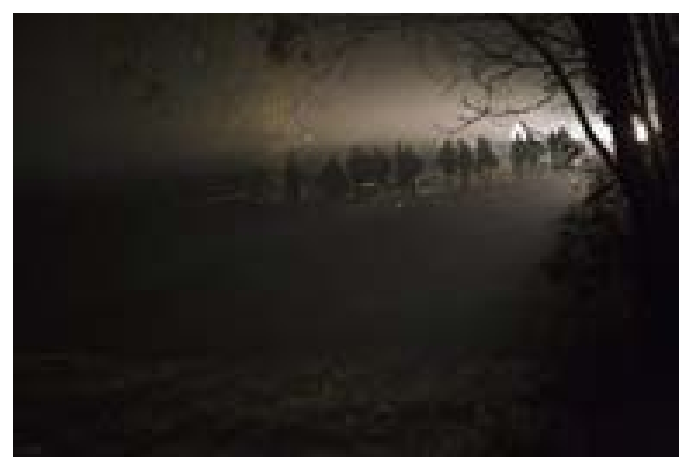

En otras imágenes, donde el énfasis no está en esta relación contenedor/contenido, se observan escenas donde el refugiado se convierte en un objeto o ha sido despersonificado a través de su representación como silueta, más allá de la masificación misma. Por ejemplo, la imagen de la izquierda nos sitúa en el punto de vista de un testigo presenciando un hecho que parece «sospechoso», ya que representa una irrupción de un grupo de sombras que, al ir por la noche, transmiten el deseo de no ser descubiertos. Presentados como infractores de normas sociales o, como Becker (2009c) proponía, señalados como outsiders o marginales.

Este efecto de entrar a escondidas es alcanzado a través de la función poética de la imagen, con el juego y contraste entre luces y sombras. Al haber un único punto de iluminación en la esquina superior, desde donde camina este grupo, se resaltan las siluetas andantes o, incluso, se desfiguran por la sombra que proyectan sus cuerpos. Además, este elemento de iluminación permite que destaquen la bruma y la niebla en el escenario boscoso ${ }^{36}$, remitiendo al imaginario colectivo de lo sobrenatural y lo místico, ampliando la distancia con el espectador, al representar aquello que queda fuera del entendimiento y control del ser humano (brujas, espectros, espíritus, etc.). Todos estos elementos, acompañados del predominante color negro, comunican un sentimiento negativo o de desasosiego (al ser este color asociado con el vacío o la muerte). Es por ello que, a pesar de no estar representada la masa como tal, sí sostiene el mensaje de la «entrada interminable» de extraños, que además buscan ocultarse en las sombras.

En contraste se encuentra la siguiente imagen, que manifiesta la masificación a través de la metáfora de las montañas de chalecos, tras el «tsunami de Lesbos» (titular de la noticia), donde nuevamente con un juego de palabras se coloca este evento bajo el marco de una catástrofe, que deja a su paso destrucción y miseria. Elementos que resal-

${ }^{36}$ Elemento que además suele representar un espacio inseguro, donde pueden ser encontrados todo tipo de enemigos y peligros, contrario a la seguridad ofrecida por lo conocido de la ciudad. Para más detalle, consultar Zimmer, citado en Cirlot (2001: 112), A Dictionary of Symbols. 
tan por el contraste de lo puro y verde del campo, contra el naranja brillante de los chalecos apilados como montañas de basura, reforzando esta idea de «suciedad» $\mathrm{y}$ desorden que generan las llegadas descontroladas de refugiados, rompiendo con la naturaleza y belleza del escenario de acogida que se vio «asaltado» por algo externo y artificial.

De esta forma, y al haber sido la posición discursiva predominante (pos-

\section{ILUSTRACIÓN 10}

Fotografía de El País, publicada en Marzo de 2016, tomada por M.J.C.

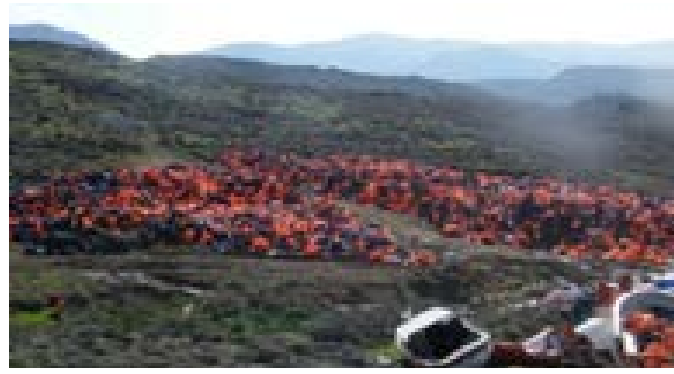
tulándose hegemónica) en la muestra, se evidencia la manera de ir construyéndose una crisis, transmitiendo sensación de alarma por la llegada de estas masas uniformes (de personas, objetos o figuras irreconocibles), legitimando la sensación de rechazo, la aparición de límites y fronteras, la necesidad de la securitización y el aumento de las ya mencionadas «narrativas antinmigratorias» (Fernández de Castro y González-Páramo, 2019c: 4).

\section{El discurso de la pena o la compasión a través de la personificación, la relación/ protección y el rescate}

\section{ILUSTRACIÓN 11}

Fotografía de El País, publicada en abril de 2016 pot Lefteris Pitaitarakis, AP.

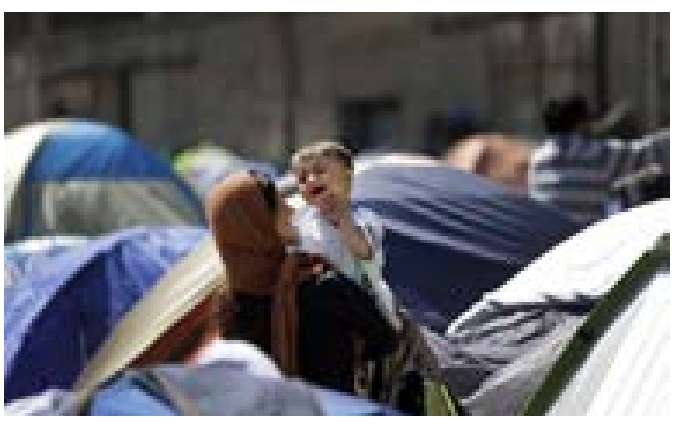

Como ya se apuntaba antes, en este discurso se encuentran varias posiciones discursivas interactuando entre sí; una de ellas corresponde a «la relación/ protección», donde frecuentemente se ve representada la figura madre/padre con su hija/o. En estas imágenes se observa una mezcla tanto de la técnica fotográfica del primer plano (persiguiendo el objetivo ya antes comentado), así como la del plano completo o medio plano, buscando resaltar la figura en sí misma, generalmente centrada para darle protagonismo sin perder el contexto de la situación. Estas imágenes buscan despertar el sentimiento de pena por el indefenso, a través de una interacción humana con la cual una buena parte de los espectadores po- 
ILUSTRACIÓN 12

Fotografía de El País, publicada en febrero de 2016, tomada por Olmo Calvo.

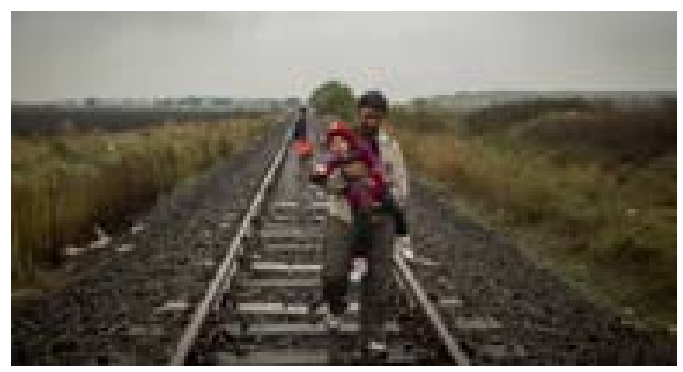

dría relacionarse (vínculo entre la figura materna/paterna). Es importante puntualizar que, contrario a lo que se esperaba encontrar antes de comenzar la investigación ${ }^{37}$, no solo se representa a la mujer junto a la presencia de la niñez, como ese ícono que simboliza la familia, sino que, en la mayoría de los casos de la muestra, predomina la presencia masculina. Si bien es interesante destacar que donde se retrata a la mujer como madre protectora la escena representa esa «estabilidad» de estar asentados y resguardados ya del peligro, mientras que al presentar a los padres tienden a ser escenarios de mayor estrés o preocupación, donde se muestran condiciones de adversidad y situaciones mucho más dinámicas, reforzando los estereotipos de género, donde la imagen de la mujer es utilizada para comunicar vulnerabilidad y pasividad, mientras que la del hombre se utiliza para la actividad más fuerte, como el protector de la familia. Por ejemplo, en la imagen superior izquierda ${ }^{38}$ puede observarse a un padre cargado a su hijo mientras caminan en las afueras, durante un día de condiciones climatológicas adversas. En esta imagen, la figura padre/hijo es la protagonista al estar centrada y en primer plano, sin que las vías de tren pierdan relevancia en la composición de la imagen. Muy al contrario, son utilizadas para simbolizar la lucha constante en ese camino «interminable» mientras se busca la protección de los hijos, contrastando una escena de desgracia frente a un elemento que alguna vez representó el progreso de la sociedad (el ferrocarril). Otra mirada a esta imagen es la de la representación estereotípica de los «indocumentados», frecuentemente retratados caminando sobre las vías del tren para no ser descubiertos, o montando vagones en movimiento buscando cruzar las fronteras ${ }^{39}$.

${ }^{37}$ En otros estudios consultados se habla del uso de la imagen de la mujer como estrategia para despertar empatía, pena o impotencia, incentivando la donación. Ver, por ejemplo, Lenette (2017), «Visual Depictions of Refugee Camps: (De)constructing Notions of Refugee-ness?».

${ }^{38}$ Imagen encontrada en los tres diarios al haber pertenecido a la serie «Supervivientes en búsqueda de refugio». Ésta ganó el Premio de Fotografía Luis Valtueña (2015) y tuvo gran alcance al ser expuesta en el Centro Cibeles.

${ }^{39}$ Estereotipos más bien extendidos en Latinoamérica, que pareció interesante proponer como lectura adicional. 
Ahora, pasando a la posición discursiva del «Rescate», en estas fotografías predomina la técnica del primer plano, destacando el lado personal, íntimo y emotivo que genera la cercanía del fotógrafo con el sujeto retratado. Pretendiendo alcanzar un mejor entendimiento de las emociones de los refugiados, al cobrar relevancia las miradas, los gestos o las facciones de los rostros, más allá del entorno o el contexto. Con estas tomas el espectador se convierte en un observador privilegiado, al cual le ofrecen un asiento en primera fila donde pueda obtener un acercamiento a estos «extraños» de fuera. Sin embargo, en la búsqueda por hacer énfasis en la persona y transmitir al espectador esa emocionalidad se fortalece la intención de despertar pena o compasión por el sufrimiento ajeno, provocando de manera indirecta que los refugiados retratados resulten más bien un espectáculo o escena de penuria que hay que presenciar.

\section{ILUSTRACIÓN 14}

Fotografía de El País, publicada en enero de 2016, Cordon Press.

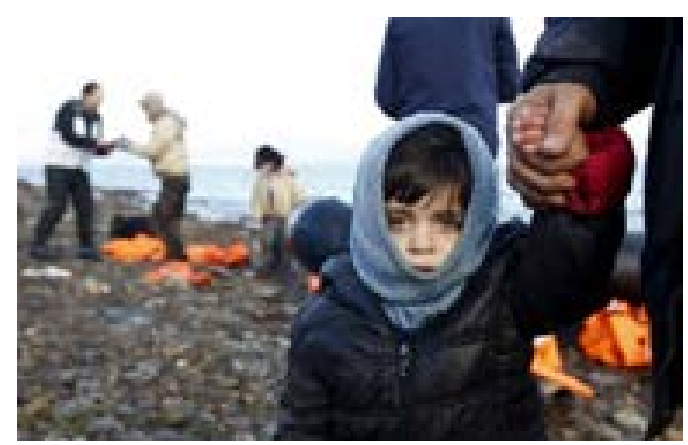

\section{ILUSTRACIÓN 13}

Fotografía de El Mundo, publicada en octubre de 2015, tomada por Alkis Konstantinidis, Reuters.

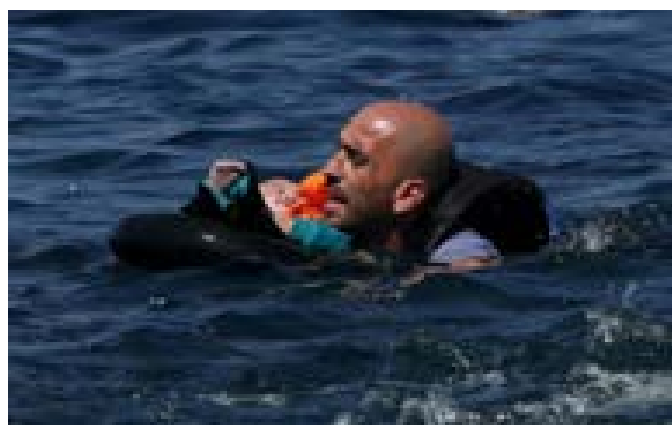

Es así que, entre las imágenes en esta posición discursiva, destacan como elemento principal los rostros reflejando dicho sufrimiento, preocupación o desaliento, así como la presencia de familias, adultos cargando a niños, o niños siendo rescatados, representando ese vínculo emocional que pretende resaltar la necesidad de cuidado y protección. Tal como lo sugiere la imagen a la izquierda, que busca transmitir un sentimiento de tristeza y vulnerabilidad, así como el mensaje de ayuda o rescate, a través del contraste de colores y símbolos. También, la composición y el juego con los planos permite inferir la intención del fotógrafo, de enfocar la atención en la mirada del niño sirio ${ }^{40} \sin$ perder de vista el símbolo de protección o cuidado que representa la mano alrededor de

40 Los elementos relacionados con la presencia de la niñez en las imágenes serán retomados y tratados en un apartado adicional sobre el discurso de la inocencia. 
la suya. Omitiendo, sin embargo, a quien en este caso personifica esta protección más directamente (el padre o persona adulta que le acompaña), al dejarlo fuera del encuadre. Todo ello mientras uno es partícipe también de la escena desenvuelta en el fondo, donde dos adultos interactúan tras la llegada del bote ubicado entre el niño y ellos. Haciendo que uno se cuestione quién acompañaba al pequeño, o si es que llegó solo y quien lo guía es un rescatista. Aquí, además, vuelven a aparecer estos elementos icónicos que simbolizan la llegada de los refugiados (los chalecos esparcidos, de nuevo como basura), que con su característico color naranja contrastan con la pureza transmitida a través de la tonalidad azul/grisácea ${ }^{41}$ de la imagen.

\section{ILUSTRACIÓN 15}

Fotografía de El Mundo, publicada en diciembre de 2015, Reuters.

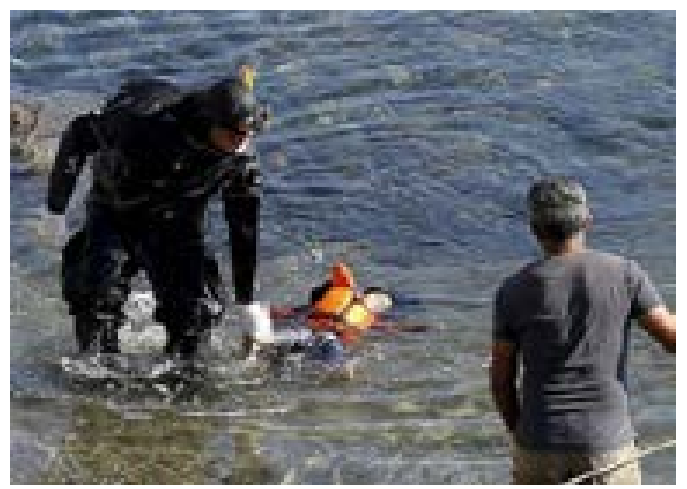

Para concluir con este discurso, parece necesario entresacar una imagen singular que representa una contrapostura a la de «La personificación» (y que ciertamente se opone a la forma de representar la muerte de Aylan ${ }^{42}$, tan solo tres meses después de la publicación de su fotografía en los medios). Esta escena fotografiada en plano completo y tomada a cierta distancia permite observar los elementos de la inocencia representada por la niñez y la necesidad de protección del adulto. Desenvolviendo, sin embargo, una situación que representa la consecuencia de una falta de acción (en este caso no haber recibido ayuda a tiempo). A pesar de que el rescate es primordialmente mostrado a través de estos acercamientos a los rostros, para resaltar la penuria experimentada, en este caso se visibiliza que la pena es transmitida también a través de situaciones que establecen cierta lejanía con el espectador, al mostrar una escena cruel y ruda, que captura el momento en el que el cadáver de un niño es manipulado y extraído del mar como un objeto o un «resto» arrastrado

${ }^{41}$ Con esta atmósfera pálida resalta la solemnidad con cierta melancolía. A su vez, al ser el azul un color frío, transmite profundidad acompañada del simbolismo del mar, representando la inmensidad de la naturaleza. Para mayor detalle sobre el significado de los colores, consultar Bellantoni (2005), If It's Purple, Someone's Gonna Die: The Power of Color in Visual Storytelling.

${ }^{42}$ Es importante mencionar que la imagen de Aylan que forma parte de este discurso no ha sido entresacada para su análisis pormenorizado para no redundar en lo que otras investigaciones han trabajado más extensamente. 
hasta ser removido. En dicha imagen, plana en cuanto a sus colores (si exceptuamos el color naranja del icónico chaleco, que resalta por su ineficacia en esta escena), se puede presenciar la cosificación de los refugiados, visibilizando la otra cara del símbolo-herramienta del rescate, al evidenciar su fracaso o ineficacia. Igualmente, es a través de esta (atípica) imagen, que, además de despersonificar al refugiado, se pone de relieve la despersonificación del rescatista, que objetualiza a la víctima y descarga de emocionalidad la escena del rescate.

\section{El discurso incriminatorio a través de la criminalización/vandalismo.}

Entre estas imágenes de la muestra no predomina algún plano fotográfico específico, sino que se observan diferentes intencionalidades del fotógrafo, según dónde quiere que nos detengamos a observar, en función de la escena y el mensaje que se desee destacar. Por ejemplo, en la imagen de la izquierda es posible ser partícipes del miedo que las mujeres retratadas están sintiendo, al presentar en un plano detalle el rostro de la mujer inconsciente recargada en una ventana y las miradas aterradas que sus-

\section{ILUSTRACIÓN 16}

Fotografía de El Mundo, publicada en septiembre de 2015, AFP.

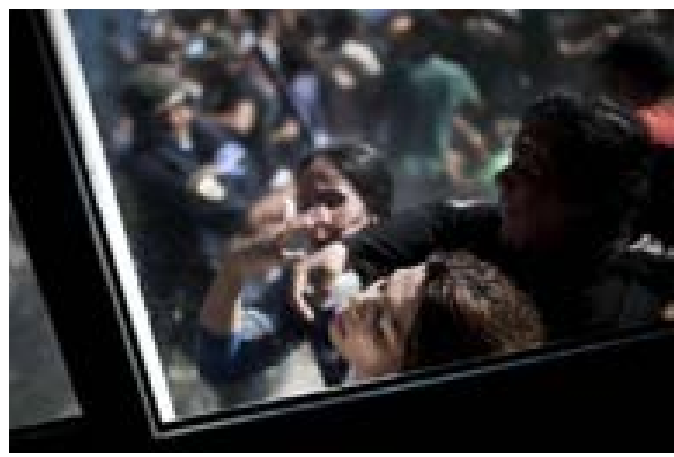
cita alrededor. Al detener nuestra atención en este punto focal, se puede observar cómo ella es atendida o protegida por dos mujeres más (nuevamente reforzando el estereotipo de género, donde la mujer comunica vulnerabilidad), mientras que, al mismo tiempo, puede uno ser testigo de la riña o el disturbio en el fondo, que fue el causante de todo. Así mismo, esta escena ubica al espectador con la lejanía o espacio apropiado para presenciar este altercado provocado por los refugiados, sin correr peligro alguno al estar distanciado y «protegido» por esa ventana que lo separa del disturbio externo.

Otro elemento interesante entre estos textos visuales es que el refugiado es plasmado como una masa o un grupo de personas (generalmente descontrolado) que amenaza la tranquilidad y seguridad de los de «dentro» y, por lo tanto, debe mantenerse «fuera». Este mensaje es transmitido a través de elementos como, por ejemplo, la presencia de una figura de poder haciendo frente a este «mar de gente» que, al enfrentarse a comportamientos conflictivos, necesita tomar una postura de protección con una mano al aire, 


\section{ILUSTRACIÓN 17}

Fotografía de $\mathrm{ABC}$, publicada en septiembre de 2015, EFE.

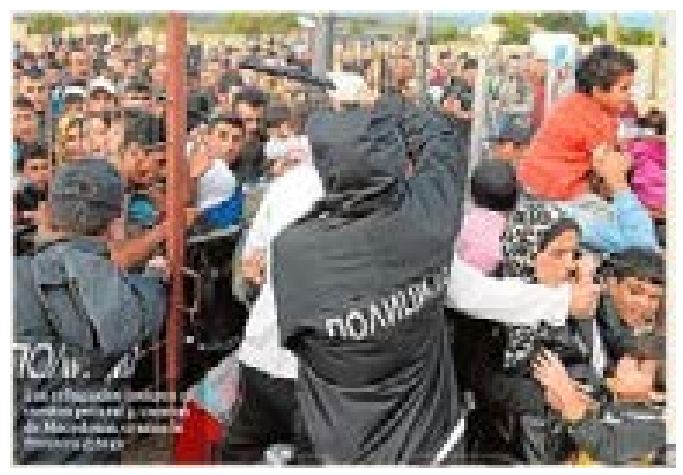

alzando la porra como símbolo de contención, orden y respeto. Otro elemento importante que es consistente en casi todas las imágenes de la muestra es la barrera física de la alambrada, que genera esta división y marca un límite entre ambos espacios, representando en algunas escenas una puerta que debe cerrarse ante el flujo de gente (como en la imagen de arriba) o que, en otras, evoca a una prisión. En estas escenas donde la protagonista es la alambrada, también cobra relevancia la actitud de los personajes ante esta «limitante», siendo representados de manera pasiva esperando tras la reja, o realizando una actividad ilegal (saltando las rejas o tratando de huir tras haber cruzado, etc.).

\section{El discurso de la inocencia a través de la niñez}

Aunque se ha hablado ya de los elementos que componen el discurso denominado «la inocencia» en algunos epígrafes anteriores, es conveniente retomar brevemente y de manera separada la presencia de la niñez, especialmente por la fuerza que tiene para potenciar o reforzar una variedad de discursos al representar mediáticamente esta problemática. Por ejemplo, Lenette (2017d), en el estudio ya previamente referenciado, habla sobre cómo la presencia de niños y niñas en las imágenes de campos de refugiados pretenden transmitir el concepto de la bondad humana y la inocencia, con la finalidad de que las audiencias sientan mayor empatía y se vean incentivadas a donar a la causa, principalmente cuando se pone en relieve que son estos actores los más desprotegidos y vulnerables al no poder cuidarse a sí mismos. Esto queda igualmente reflejado en los textos visuales que forman parte del corpus de la presente investigación, al representar a la niñez (en su mayoría sin acompañamiento de un adulto) como los principales afectados o quienes sufren más en esta travesía de la búsqueda de refugio, mostrándolos en escenarios de estrés y sufrimiento o como la consecuencia o fracaso de un rescate.

La niñez, como ya se observaba, predomina principalmente durante la representación del rescate, pero también se encuentra en algunas escenas durante el asentamiento. Aquí, las imágenes se caracterizan por estar tomadas en un primer plano o plano medio, 
a través del cual el espectador pueda «vivir» el sufrimiento y miedo que reflejan los rostros, sin perder de vista el escenario desfavorable del que están siendo víctimas en esta búsqueda de protección y asilo. Por ejemplo, en la imagen de la derecha se muestra en un primer plano a un niño sirio, de facciones estereotípicas (tez morena, cabello y ojos oscuros), caminando bajo la lluvia, a través de lo que parecería ser un campo de refugiados.

La intención del fotógrafo, al centrar la figura del niño y desenfocar el fondo, es por supuesto resaltar la postura que indica que está pasando frío o alguna especie de malestar, así como su rostro, que refleja temor y angustia. Además, es posible observar que en sus manos lleva dos vasos $\mathrm{y}$, aunque el contenido no logra verse con claridad, la figura podría asemejarse a la de un indigente pidiendo limosna. Es interesante, si se considera que la niñez es símbolo también de la promesa de un futuro (Cirlot, 2001), que en este caso, y a diferencia de una imagen entresacada previamente, él no está observando directamente al espectador, sino que su mirada se encuentra perdida en el horizonte, como quien no sabe qué esperar justamente de ese futuro que él representa.

\section{ILUSTRACIÓN 19}

Fotografía de El País, publicada en abril de 2016, tomada por Stoyan Nenov, Reuters.

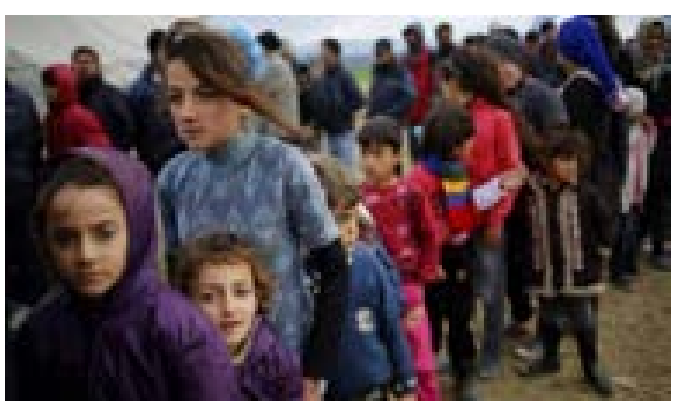

Según Cirlot (2001), la niñez representa también el periodo de pureza en la vida, la etapa en la cual la naturaleza se encarga de dar sin ningún esfuerzo por «merecer»y sin necesidad de preocuparse por ello. Sin embargo, en las imágenes de la muestra frecuentemente se observa todo lo contrario, niños retratados en escenarios que comunican suciedad en vez de pureza, o donde destacan las condiciones extremas en las que están viviendo, plasmándose rostros y posturas que transmiten desaliento o temor, sugiriendo al espectador que la vida más bien les «ha quitado» aquello que poseían, sin tener ellos culpabilidad/responsabilidad alguna. Se refleja así una niñez como representación del desconocimiento e inocencia, que limita el entendimiento de lo que acontece en el presente y, sobre todo, que genera incertidumbre sobre lo que les depara el futuro, situándolos como actores pasivos y sin poder 
alguno, que dependen enteramente de la «buena obra» de alguien más y que, cuando esa ayuda ha fracasado, son los que menos oportunidades tienen de sobrevivir. Es por todo ello que, si bien estas representaciones son potentes para transmitir la inocencia de la que se ha hablado, frecuentemente son útiles también para reforzar el discurso de la pena o la compasión, como ya se mostró en un epígrafe anterior.

\section{El discurso de la espectacularización y la exclusión a través de la miseria / el infortunio}

Entre las imágenes que destacan en este discurso predomina la técnica fotográfica del plano completo y el plano medio al tener la intención de brindar una «perspectiva completa» del escenario, actividad o suceso representado y evidenciar las dificultades a las que se han tenido que enfrentar durante su largo recorrido o la forma en que están viviendo. Intencionalidad que queda expuesta al contemplar que las imágenes de la muestra retratan justo las etapas de paso en función del eje «trayecto/travesía», reflejando o bien el peregrinaje (sorteando todo tipo de adversidades en el camino) o bien la etapa de asentamiento (en campos de refugiados o campos improvisados mientras están a la espera de alguna respuesta). En cualquier caso, se pretende reflejar un escenario tan completo como sea posible ${ }^{43}$, que permita leer la imagen a través del conjunto de elementos, para «comprender» por lo que han pasado los refugiados. Sin embargo, terminan mostrándose los acontecimientos como parte de un espectáculo del infortunio o miseria, realzando el espacio entre «nosotros» y «ellos», dificultando la empatía al presentar escenarios que distan mucho de «nuestra realidad» o lo que co-

\section{ILUSTRACIÓN 20}

Fotografía de $\mathrm{ABC}$, publicada en enero de 2016, AFP

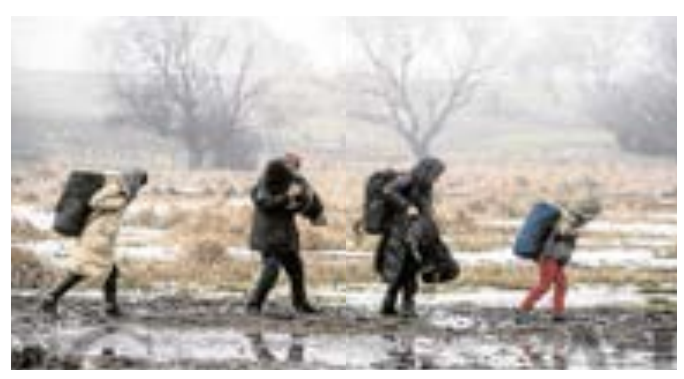
nocemos.

Por ejemplo, en las imágenes que hablan sobre la etapa de la partida / el camino se pueden observar escenas que parecerían extraídas de una película. En ellas se presenta a los actores-sujeto en acción, viéndose enfrentados a situaciones adversas debido a barreras naturales como ríos, nieve, barro, etc., obstáculos que deben sortear si quieren sobrevivir y llegar a «su destino». Tal es el caso de la

${ }^{43}$ Contemplando que el fotógrafo selecciona el fragmento de escena que quiere que el espectador vea. 
ilustración 20, donde se muestra a una familia ${ }^{44}$ muy abrigada, realizando un arduo esfuerzo por cruzar ese campo desolado y en condiciones climatológicas desfavorables, mientras llevan sus pertenencias en grandes mochilas que transmiten la pesadez de su carga, simbólica y física.

Ahora bien, cuando se muestra al refugiado en la etapa de asentamiento ya «instalado» en un campo, el escenario no es más alentador. Un ejemplo de ello es la siguiente imagen, donde, aparentemente, se está representando una escena de la vida diaria, que queda evidenciada por el tendedero y la ropa mostrados en un primer plano (desenfocado). En este escenario se presenta a una mujer, en-

\section{ILUSTRACIÓN 21}

Fotografía de El País, publicada en marzo de 2016, tomada por Zoltan Balogh, EFE

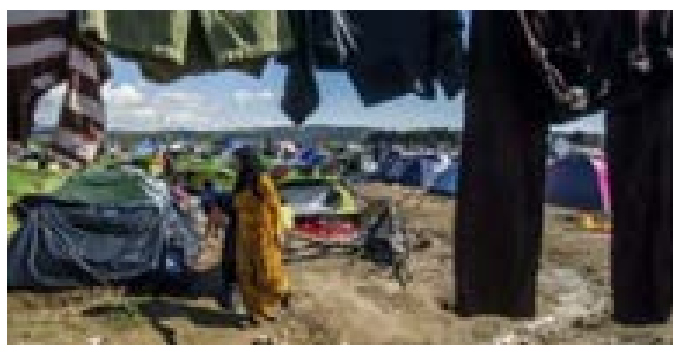
cuadrada en el centro, que lleva cargando lo que parece ser una prenda de ropa, probablemente inmersa en esta actividad e intentando recuperar dicha cotidianidad en este «hogar temporal».

Sin embargo, al mirar la conjunción de elementos es cuando resuena que esta no es una escena «típica», ya que la actividad se desenvuelve en un campo donde predomina un suelo de barro, transmitiendo la imagen de suciedad y reforzando el imaginario de la pobreza y la marginación. Otro elemento a destacar son las múltiples casas de campaña que aparecen en el último plano, comunicando la idea de abandono al estar en malas condiciones, mientras que refuerzan (aunque no de manera directa) la idea de la masividad.

Por último, otra forma de retratar la etapa de asentamiento y que fortalece el discurso de la exclusión a través de la miseria consiste en un paralelismo con la manera de representación del sinhogarismo. Al presentar escenas donde los refugiados se plasman como vagabundos en las calles, echados en el suelo, durmiendo sobre cartones o apenas cubiertos por mantas. Mostrándolos como «sujeto amenazante para los individuos que transitan, para los vecinos, para la higiene, para la imagen pública y para la sociedad en su conjunto» (Serrano y Zurdo, 2013: 120).

Ejemplo de ello es la ilustración 22, donde se observa unas figuras que yacen en el suelo descalzas (a las cuales no se les ve el rostro) y se encuentran bajo un muro que les sirve como vehículo para expresarse y enviar un mensaje al Gobierno alemán. De esta

\footnotetext{
${ }^{44}$ A quienes, a pie de foto, se les describe de manera vaga como «unos inmigrantes...».
} 
ILUSTRACIÓN 22

Fotografía de El Mundo, publicada en septiembre de 201,5 tomada por Alberto Di

Lolli, EFE

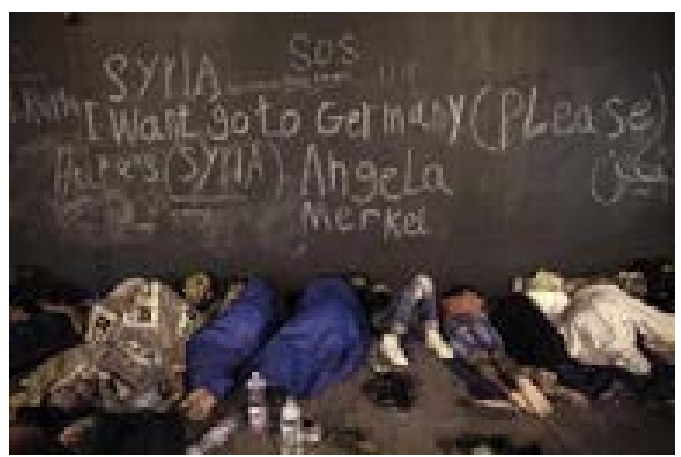

forma, al plasmar a los refugiados como bultos en el suelo, se les despersonaliza, convirtiéndolos en un estorbo o lastre para la sociedad que afecta a la higiene y representa una carga/impedimento al desarrollo, al ser personas necesitadas de ayuda o caridad que poco (o nada) pueden aportar a los países receptores. Incrementando así la distancia con el espectador al reforzarse la idea de la «otredad» y colocar a los refugiados en una esfera lejana a la nuestra.

\section{CONCLUSIONES}

Con la presente investigación se destaca la importancia de considerar los textos visuales como materiales clave para reconstruir el sistema de discursos difundido por los medios acerca de la «crisis de refugiados» (crisis migratoria/europea). Principalmente, debido a que el tratamiento mediático de esta problemática se ha abordado en su mayoría desde el plano de lo textual y, sobre todo, considerando la potencialidad que tienen las imágenes dentro de los procesos de reproducción de la «realidad», aunado a la influencia de los medios para establecer la agenda política e influir en la forma en la cual la sociedad percibe esa realidad.

Tras analizar la muestra de textos visuales se ha identificado que las representaciones de los refugiados ahí establecidas se desarrollan principalmente en función de la configuración narrativa relacionada con «El trayecto / la travesía», es decir, que la mirada parte desde la historia o el camino que se han visto obligados a seguir. Y es hacia el interior de esa narrativa que se les refleja o bien como sujetos o bien como objetos en ese peregrinaje, tendiendo a destacar un mensaje diferente según la etapa de paso experimentada. Por lo tanto, surgen en estas interacciones entre ambos ejes los siguientes cinco discursos: el alarmista de la invasión a través de la masificación; el de la pena o compasión a través de la personificación, protección y el rescate; el incriminatorio a través de la criminalización; el de la inocencia a través de la niñez; y el de la espectacularización y exclusión a través de la difusión de la miseria. 
A través del análisis sociohermenéutico se ha logrado constatar, primero, la presencia de dos discursos predominantes en la muestra y, segundo, la existencia de una transformación de los mismos, en función de la narrativa del trayecto. Siendo el discurso alarmista a través del encuadre de la masificación el que se postula hegemónico y que, al enfocarse en retratar el momento de la partida (y en algunos casos el de la llegada de los refugiados a los países receptores), funciona como un vehículo potente para comunicar el nacimiento de una crisis, ante la «invasión» de una multitud de gente externa y extraña (outsiders), legitimando de esta forma el levantamiento de fronteras e intentando justificar la necesidad del proteccionismo y marcar una división entre quien pertenece y quien no pertenece. Posteriormente se observa que conforme avanza la narrativa del trayecto (cuando los medios representan la llegada/final y en ocasiones el asentamiento) ese discurso de alarma se va convirtiendo en el de la pena y compasión, a través de la contrapostura a la masificación: la personificación de los refugiados. Mostrándolos como individuos victimizados, desprotegidos y/o necesitados de rescate.

Es así que estos discursos transmitidos a través de las imágenes analizadas refuerzan los estereotipos existentes sobre los refugiados o construyen en favor de la confusión terminológica (presente en el plano de lo textual) al representar situaciones que pueden evocar al imaginario de la inmigración (ilegal). Por lo tanto, se engloba así la problemática en un concepto genérico de «crisis», que favorece la estigmatización de la otredad y se establece como ejercicio de violencia simbólica, al representar a estos recién llegados como sujetos/objetos de ayuda, o como una carga u obstrucción al desarrollo social.

Por último, si se contempla que, «bajo el objetivo de la visualización, se ha llegado a una simplificación de la situación, que más allá de ayudar se limita a señalar» (Gutiérrez, 2019) ${ }^{45}$, resultaría interesante también incorporar las voces de los refugiados en el estudio de las representaciones visuales ${ }^{46}$ para identificar el grado en que se ven (o no) representados por estas imágenes difundidas en los medios. De forma que puedan explorarse vías que permitan dicha visualización, humanizando sus representaciones y reflejándolos como actores sociales relevantes para el progreso y crecimiento social.

45 Opinión expresada durante la sesión «Las personas refugiadas en los medios de comunicación: luces y sombras del protagonismo mediático», en la jornada internacional Universidad Complutense de Madrid y ACNUR.

46 A través de metodologías como las historias de vida o la foto-elicitación. 


\section{REFERENCIAS}

Abril, G. (2012). «Tres dimensiones del texto y de la cultura visual». En IC-Revista Científica de Información y comunicación (9), págs. 15-35.

Banco Mundial (2018). Población de refugiados por país o territorio de asilo. Disponible en https://datos.bancomundial.org/indicador/SM.POP.REFG?end=2017\&start $=2010$ (diciembre 2018).

Becker, H. (2009). Outsiders: Hacia una sociología de la desviación, Buenos Aires: Siglo Veintiuno Editores.

Belarbi, A. (2004). «La dinámica de las representaciones sociales». En Revista CIDOB d'Afers Internationals (66-67), págs. 81-97.

Bellantoni, P. (2005). If It's Purple, Someone's Gonna Die: The Power of Color in Visual Storytelling, Oxford: Focal Press.

Berger, J. (1972). Ways of Seeing, Londres: British Broadcasting Association and Penguin.

Berry, M. et. al. (2015). Report prepared for the United Nations High Commission for Refugees - Press Coverage of the Refugee and Migrant Crisis in the EU: A Content Analysis of Five European Countries. Disponible en https://www.unhcr.org/protection/operations/56bb369c9/press-coverage-refugee-migrant-crisis-eu-content-analysis-five-european.html (enero 2018).

CEAR (2016). Informe 2017: Las personas refugiadas en España y Europa. Comisión Española de Ayuda al Refugiado (CEAR), Madrid. Disponible en https://www.cear. es/wp-content/uploads/2017/06/Informe-Anual-CEAR-2017.pdf (octubre 2018).

CEAR (2017). Informe 2018: Las personas refugiadas en España y Europa. Comisión Española de Ayuda al Refugiado (CEAR), Madrid. Disponible en https://www.cear. es/wp-content/uploads/2018/06/Informe-CEAR-2018.pdf (octubre 2018).

CEAR (2018). Dos años del acuerdo entre la UE y Turquía. Comisión Española de Ayuda al Refugiado (CEAR), Madrid. Disponible en https://www.cear.es/dos-anos-delacuerdo-la-ue-turquia/ (octubre 2018).

Cirlot, J. (2001). A Dictionary of Symbols, Londres: Taylor \& Francis.

Comisión Europea (2011). Qualitative Eurobarometer: Migrant Integration. Aggregate Report May 2011. Disponible en http://ec.europa.eu/commfrontoffice/publicopinion/archives/quali_en.htm (octubre 2018).

Comisión Europea (2018). Eurobarómetro Standard 90, Opinión pública en la unión europea. Informe Nacional. Disponible en https:/ec.europa.eu/spain/sites/spain/files/st90-pres-repes-13.02.2019_final_version.pdf (mayo 2019). 
Conde, F. (2009). Análisis sociológico del sistema de discursos, Madrid: CIS (Colección Cuadernos Metodológicos, n. $\left.^{\circ} 43\right)$,

Dyer, R. (1999). «The Role of Stereotypes», en Marris, P. y Thornham, S. Media Studies: A Reader, Edinburgh: University Press.

Escuela de Negocios (2014). Qué es y para qué sirve Google Trends. Marketing Digital: Escuela de Negocios y Dirección. Disponible en https://br.escueladenegociosydireccion.com/business/marketing-digital/google-trends/ (agosto 2019).

Fernández de Castro, P. \& González-Páramo, A. (2019). La franquicia antimigración: Cómo se expande el populismo xenófobo en Europa. PorCausa Análisis. Disponible en https://porcausa.org/wp-content/uploads/2019/04/Informe_Franquicia_Antimigratoria_porCausa_abril_2019.pdf (mayo 2019).

Foucault, M. (1991). Saber y verdad, Madrid: La Piqueta.

Georgiou, M. \& Zaborowski, R. (2017). Council of Europe report - Media coverage of the «refugee crisis»: A cross-European perspective. London School of Economics and Political Science. Disponible en https://edoc.coe.int/en/refugees/7367-media-coverage-of-the-refugee-crisis-a-cross-european-perspective.html (enero 2018).

Goffman, E. \& Guinsberg, L. (2006). Estigma: La identidad deteriorada (Biblioteca de Sociología), Buenos Aires: Amorrortu.

Gutiérrez, M. E. (abril 2019). Las personas refugiadas en los medios de comunicación: luces y sombra del protagonismo mediático. En M. Fernández (Presidencia). No dejes a nadie atrás. Las personas refugiadas y los retos de la comunicación. Jornada internacional Universidad Complutense de Madrid y ACNUR, Madrid.

Hall, S. y Open University (1997). Representation: Cultural representations and signifying practices, Londres: Sage, en asociación con la Open University.

Ibáñez, J. (1986). Más allá de la Sociología. El grupo de discusión: técnica y crítica, Madrid: Siglo XXI.

Jefatura del Estado (2009). BOE: Ley 12/2009, de 30 de octubre, reguladora del derecho de asilo y de la protección subsidiaria. REF BOE-A-2009-17242, Boletín Oficial del Estado.Disponibleenhttps://www.boe.es/buscar/pdf/2009/BOE-A-2009-17242-consolidado.pdf (enero 2019).

Lenette, C. (2017). «Visual Depictions of Refugee Camps: (De)constructing Notions of Refugee-ness?», en Liamputtong, P. (eds): Handbook of Research Methods in Health Social Sciences, Singapore: Springer. https://doi.org/10.1007/978-981-10-27796_47-1.

Lippmann, W. (1921). Public opinion, Nueva York: Harcourt, Brace and Co.

McCombs, M. \& Evatt, D. (1995). «Los temas y los aspectos: explorando una nueva dimensión de la agenda setting». En Comunicación y Sociedad, 8 (1), págs. 7-32. 
OIM (2006). Derecho Internacional sobre Migración: Glosario sobre Migración (7). Disponible en https://publications.iom.int/system/files/pdf/iml_7_sp.pdf (enero 2018)

Onghena, Y. (2015). La Crisis de Valores: La Propia Unión Europea en Tela de Juicio. Investigadora sénior asociada, CIDOB (Barcelona Centre for International Affairs). Disponible en https://www.cidob.org/publicaciones/serie_de_publicacion/monografias/monografias/europa_ante_la_crisis_de_los_refugiados_10_efectos_colaterales (enero 2018)

ONU (1951). Convención sobre el Estatuto de los Refugiados. Suiza, 28 de julio de 1951, Serie Tratados de Naciones Unidas, vol. 330, n. ${ }^{\circ} 2545$, pág. 137. Disponible en https://www.acnur.org/5b0766944.pdf

Panofsky, E. (1955). Meaning in the visual arts: papers in and on art history, Harmondsworth: Penguin.

Ruiz-Aranguren, M. \& Cantalapiedra-González, M. J. (2018). «La imagen negativa de la inmigración en los medios: ¿cuestión de estrategia?». En Estudios sobre el Mensaje Periodístico, 24 (1), págs. 361-378.

Sassen, S. (2013). Inmigrantes y ciudadanos. De las migraciones masivas a la Europa fortaleza, Madrid: España Editores.

Serrano, A. \& Zurdo, Á. (2013). «Representaciones audiovisuales de las personas sin hogar». En Revista Española de Sociología (20), págs. 105-137.

UNHCR (2017). Global Trends: Forced Displacement in 2017. Disponible en https:// www.unhcr.org/globaltrends2017/ (enero 2018)

Wright, T. (2002). «Moving images: The media representation of refugees». En Visual Studies, 17(1), págs. 53-66. 